OPEN ACCESS

Edited by:

Rupesh Kailasrao Deshmukh,

Laval University, Canada

Reviewed by:

Durgesh Kumar Tripathi,

Banaras Hindu University, India

Dharmendra Singh,

Indian Agricultural Research Institute

(ICAR), India

${ }^{*}$ Correspondence: Paula Cartes

paula.cartes@ufrontera.c

Specialty section:

This article was submitted to

Plant Nutrition

a section of the journal

Frontiers in Plant Science

Received: 26 January 2017

Accepted: 10 April 2017

Published: 25 April 2017

Citation:

Pontigo S, Godoy K, Jiménez H, Gutiérrez-Moraga A, Mora ML and Cartes P (2017) Silicon-Mediated Alleviation of Aluminum Toxicity by Modulation of Al/Si Uptake and Antioxidant Performance in Ryegrass Plants.

Front. Plant Sci. 8:642. doi: 10.3389/fpls.2017.00642

\section{Silicon-Mediated Alleviation of Aluminum Toxicity by Modulation of Al/Si Uptake and Antioxidant Performance in Ryegrass Plants}

\author{
Sofía Pontigo 1,2, Karina Godoy², Héctor Jiménez ${ }^{1}$, Ana Gutiérrez-Moraga ${ }^{2,3}$, \\ María de la Luz Mora ${ }^{2,4}$ and Paula Cartes $2,4 *$ \\ ${ }^{1}$ Programa de Doctorado en Ciencias de Recursos Naturales, Universidad de La Frontera, Temuco, Chile, ${ }^{2}$ Center of \\ Plant-Soil Interaction and Natural Resources Biotechnology, Scientific and Technological Bioresource Nucleus \\ (BIOREN-UFRO), Universidad de La Frontera, Temuco, Chile, ${ }^{3}$ Departamento de Producción Agropecuaria, Facultad de \\ Ciencias Agropecuarias y Forestales, Universidad de La Frontera, Temuco, Chile, ${ }^{4}$ Departamento de Ciencias Químicas y \\ Recursos Naturales, Facultad de Ingeniería y Ciencias, Universidad de La Frontera, Temuco, Chile
}

Silicon (Si) has been well documented to alleviate aluminum (Al) toxicity in vascular plants. However, the mechanisms underlying these responses remain poorly understood. Here, we assessed the effect of Si on the modulation of Si/Al uptake and the antioxidant performance of ryegrass plants hydroponically cultivated with $\mathrm{Al}(0$ and $0.2 \mathrm{mM})$ in combination with $\mathrm{Si}(0,0.5$, and $2.0 \mathrm{mM})$. Exposure to $\mathrm{Al}$ significantly increased Al concentration, mainly in the roots, with a consequent reduction in root growth. However, Si applied to the culture media steadily diminished the Al concentration in ryegrass, which was accompanied by an enhancement in root dry matter production. A reduced concentration of Si in plant tissues was also observed when plants were simultaneously supplied with Al and Si. Interestingly, Si transporter genes (Lsi1 and Lsi2) were down-regulated in roots after Si or Al was applied alone; however, both Lsi1 and Lsi2 were up-regulated as a consequence of Si application to Al-treated plants, denoting that there is an increase in Si requirement in order to cope with Al stress in ryegrass. Whereas Al addition triggered lipid peroxidation, Si contributed to an attenuation of Al-induced oxidative stress by increasing phenols concentration and modulating the activities of superoxide dismutase (SOD), catalase, peroxidase, and ascorbate peroxidase antioxidant enzymes. Differential changes in gene expression of SOD isoforms (Mn-SOD, Cu/Zn-SOD, and Fe-SOD) and the profile of peroxide $\left(\mathrm{H}_{2} \mathrm{O}_{2}\right)$ generation were also induced by $\mathrm{Si}$ in Al-stressed plants. This, to the best of our knowledge, is the first study to present biochemical and molecular evidence supporting the effect of $\mathrm{Si}$ on the alleviation of Al toxicity in ryegrass plants.

Keywords: silicon, aluminum, Si transporter genes, phenols, antioxidant enzymes, SOD isoforms genes

\section{INTRODUCTION}

Aluminum ( $\mathrm{Al}$ ) toxicity represents one of the main yield-limiting factors for crops in acid soils (von Uexküll and Mutert, 1995). Under acidic conditions, large and toxic amounts of $\mathrm{Al}^{3+}$ become available to plants, thereby affecting a wide range of physical, cellular, and molecular processes, with a consequent reduction in plant growth (Kochian et al., 2005; Mora et al., 2006; Cartes et al., 2010, 2012; Ryan and Delhaize, 2010; Singh et al., 2017). Alterations in the structure and/or functions of 
cell wall components (Horst et al., 2010), plasma membrane properties (Yamamoto et al., 2001), nutrient homeostasis (Delhaize and Ryan, 1995; Gupta et al., 2013; Singh et al., 2017), and signal transduction pathways (Matsumoto, 2000; Ma et al., 2002; Sivaguru et al., 2003; Goodwin and Sutter, 2009) can be induced as a consequence of $\mathrm{Al}$ binding to numerous cell sites. In most plant species, reactive oxygen species (ROS) production can also be induced by Al toxicity (Kochian et al., 2005), leading to oxidative damage of biomolecules and biological membranes (Yamamoto et al., 2001, 2002, 2003; Singh et al., 2017).

To cope with the deleterious effects of $\mathrm{Al}$, plant species have developed diverse mechanisms, which are generally associated with $\mathrm{Al}$ exclusion (also referred to as avoidance or resistance) and/or internal tolerance mechanisms (e.g., Barcelo and Poschenrieder, 2002; Kochian et al., 2005; Poschenrieder et al., 2008). Briefly, exclusion mechanisms involve the root exudation of organic acid anions and/or phenolic compounds, which bind $\mathrm{Al}^{3+}$ and limit its uptake into the cytosol. Tolerance mechanisms comprise internal detoxification by forming Al complexes with organic substances in the cytosol, compartmentalization in the vacuole, and enhanced scavenging of ROS (e.g., Barcelo and Poschenrieder, 2002; Kochian et al., 2005; Poschenrieder et al., 2008). Molecular approaches have revealed that $\mathrm{Al}$ resistance in several plant species is regulated by genes encoding membrane transporter proteins involved in the efflux of organic acid anions, including members of the ALMT (aluminum-activated malate transporters) and MATE (multidrug and toxic compound extrusion) families (Sasaki et al., 2004; Furukawa et al., 2007; Ryan et al., 2011). In addition, a bacterialtype ATP binding cassette (ABC) transporter (Huang et al., 2009) and antioxidant defense genes (e.g., Milla et al., 2002; Goodwin and Sutter, 2009; Du et al., 2010; Panda and Matsumoto, 2010) have also been implicated in Al tolerance in plants.

Over the last decades, silicon ( $\mathrm{Si}$ ) has become a focus of increasing interest in plant science, since it is considered as a beneficial element for plant growth, particularly under conditions of biotic and abiotic stress (Ma, 2004; Liang et al., 2007; Guntzer et al., 2012; Ma and Yamaji, 2015). To date, several pieces of evidence have indicated that most of the beneficial effects of $\mathrm{Si}$ depend on the differential ability of plants to take up Si. Recently, it has been reported that $\mathrm{Si}$ accumulation is ascribed to an efficient uptake system mediated by both channel-type and efflux transporters, which perform coordinated functions for effective $\mathrm{Si}$ transport from soil to roots and its subsequent distribution within the plants (e.g., Ma et al., 2006, 2007; Yamaji et al., 2008, 2012; Chiba et al., 2009; Mitani et al., 2009a,b, 2011a,b; Yamaji and Ma, 2009; Grégoire et al., 2012; Montpetit et al., 2012; Deshmukh et al., 2013; Ma and Yamaji, 2015). Overall, these transporters appear to be keys features that enable plants to gain an advantage from Si uptake. Nevertheless, the regulation of Si transporters under stress conditions remains poorly understood.

The significant role of $\mathrm{Si}$ in the toxicity associated with metals, including manganese $(\mathrm{Mn})$, iron $(\mathrm{Fe})$, cadmium $(\mathrm{Cd})$, arsenic (As), chromium $(\mathrm{Cr})$, copper $(\mathrm{Cu})$, lead $(\mathrm{Pb})$, zinc $(\mathrm{Zn})$, and $\mathrm{Al}$, has been widely reported (Li et al., 2012; Vaculík et al., 2012; Adrees et al., 2015; Liang et al., 2015; Pontigo et al., 2015; Tripathi et al., 2015, 2016). On the basis of the current evidence, Si can regulate plant resistance and/or tolerance to metal toxicity by either external (ex planta) or internal (in planta) mechanisms (Cocker et al., 1998a; Adrees et al., 2015; Liang et al., 2015; Pontigo et al., 2015; Tripathi et al., 2016). In this regard, it has been proposed that the alleviation of $\mathrm{Al}$ stress by $\mathrm{Si}$ in plants can mainly be explained by the following events: (i) Si-induced increase in solution pH (Li et al., 1996; Cocker et al., 1998a), (ii) formation of Al-Si complexes in the growth media (Barcelo et al., 1993; Baylis et al., 1994; Ma et al., 1997; Cocker et al., 1998a) or/and within the plant (Corrales et al., 1997; Cocker et al., 1998b; Britez et al., 2002; Zsoldos et al., 2003; Wang et al., 2004; Prabagar et al., 2011), (iii) exudation of organic acid anions and phenolic compounds (Barcelo et al., 1993; Cocker et al., 1998b; Kidd et al., 2001), and (iv) increase in the chlorophyll and carotenoid contents of leaves (Singh et al., 2011). Activation of the plant antioxidant system has also been reported in response to Si supply under Al stress (Shahnaz et al., 2011; Shen et al., 2014; Tripathi et al., 2016). However, to our knowledge, there is a dearth of reports regarding the molecular aspects of the effect of Si on the genes involved in antioxidant defense.

Perennial ryegrass (Lolium perenne L.) is a temperate pasture species supporting forage-based intensive dairy and beef production systems in many parts of the world. Due to elevated yields and high nutritional value, ryegrass has become one of the most commonly cultivated species in the permanent pastures of Southern Chile. Nevertheless, large areas of these pastures are sown on acidic soils, which exhibit elevated availability of toxic $\mathrm{Al}^{+3}$, thereby limiting their yield and quality (Mora et al., 2006). Furthermore, our previous studies have demonstrated that toxic levels of $\mathrm{Al}$ induced oxidative damage and activated antioxidant enzymes in ryegrass roots, including peroxidase (POD), ascorbate peroxidase (APX), and superoxide dismutase (SOD) (Cartes et al., 2010, 2012). In an attempt to identify new alternatives to alleviate the deleterious effects produced by $\mathrm{Al}$ on ryegrass, we aimed in this study to investigate the effect of $\mathrm{Si}$ on the modulation of $\mathrm{Si} / \mathrm{Al}$ uptake and the antioxidant performance of ryegrass plants subjected to $\mathrm{Al}$ toxicity.

\section{MATERIALS AND METHODS}

\section{Plant Material and Growth Conditions}

Seeds of ryegrass (L. perenne L. cultivar Nui) were soaked with $2 \% \mathrm{v} / \mathrm{v}$ sodium hypochlorite for $10 \mathrm{~min}$, washed repeatedly with distilled water, and then germinated on moist filter paper in a growth chamber at $21^{\circ} \mathrm{C}$. After 10 days, seedlings were transferred to 12 -L plastic pots containing a continuously aerated basal nutrient solution described by Taylor and Foy (1985). After 10 days in nutrient solution, ryegrass plants were treated with $\mathrm{Al}$ and Si. Aluminum (as $\mathrm{AlCl}_{3}, \mathrm{Merck}$ reagent) was added to the solution at doses of 0 and $0.2 \mathrm{mM}$. The activity of free $\mathrm{Al}^{3+}$ in the nutrient solution, calculated by Geochem-EZ (Shaff et al., 2010), corresponded to $85 \mu \mathrm{M}$. Aluminum doses were added in combination with $0,0.5$, and $2 \mathrm{mM}$ Si (as $\mathrm{Na}_{2} \mathrm{SiO}_{3}$, Merck reagent) in a completely randomized factorial design with three replicates per treatment. During the growth period, the $\mathrm{pH}$ of the solution was adjusted daily to $4.5 \mathrm{using}$ dilute $\mathrm{HCl}$ 
or $\mathrm{NaOH}$, and the nutrient solution was changed every 7 days. Plants were cultured in a greenhouse under controlled growth conditions as follows: $25 / 20^{\circ} \mathrm{C}$ day/night temperature, a $16 / 8 \mathrm{~h}$ (light/dark) photoperiod, $350 \mu \mathrm{mol} \mathrm{m} \mathrm{m}^{-2} \mathrm{~s}^{-1}$ photosynthetic photon flux (PPF) and $70-80 \%$ relative humidity. Plants were harvested 10 days after the initiation of treatments, and shoot and root samples were stored at $-20^{\circ} \mathrm{C}$ or $-80^{\circ} \mathrm{C}$ for subsequent evaluation of biochemical and molecular parameters. In addition, subsamples of fresh material were dried at $65^{\circ} \mathrm{C}$ for $48 \mathrm{~h}$ in order to determinate the dry weight as well as $\mathrm{Si}$ and $\mathrm{Al}$ concentrations.

\section{Determination of the Mineral Concentration of $\mathrm{Al}$ and $\mathrm{Si}$ in Plant Tissues}

Aluminum analysis was performed on dried roots and shoots. Plant samples were ashed at $500^{\circ} \mathrm{C}$ for $8 \mathrm{~h}$ and treated with $2 \mathrm{M}$ $\mathrm{HCl}$. After filtration of the resulting solution, the total amount of Al was quantified by flame atomic absorption spectrophotometry (FAAS) at $324.7 \mathrm{~nm}$, as described by Sadzawka et al. (2007). Silicon concentration was assayed as described by Pavlovic et al. (2013) with modifications. Dry plant samples were digested with $5 \mathrm{~mL}$ concentrated $\mathrm{HNO}_{3}$ on a hot plate at $70^{\circ} \mathrm{C}$ for approximately $5 \mathrm{~h}$. Samples were diluted with $10 \mathrm{~mL}$ of deionized water, followed by the addition of $1 \mathrm{~mL} \mathrm{HF} \mathrm{(40 \% ),} \mathrm{and} \mathrm{left}$ overnight. The following day, $5 \mathrm{~mL} 2 \%(\mathrm{w} / \mathrm{v}) \mathrm{H}_{3} \mathrm{BO}_{3}$ was added to eliminate excess $\mathrm{HF}$ and the volume of the solution was adjusted to $25 \mathrm{~mL}$ with deionized water. The Si concentration in the digested samples was determined by FAAS at $251.6 \mathrm{~nm}$. For each chemical analysis, two reference samples were included in each analytical run.

\section{Biochemical Analyses Lipid Peroxidation Assay}

Lipid peroxidation was analyzed using the thiobarbituric acid reactive substances (TBARS) assay, according to the modified method of Du and Bramlage (1992). The absorbance of the samples was measured at 532,600, and $440 \mathrm{~nm}$ in order to correct for interference generated by TBARS-sugar complexes.

\section{Determination of Total Phenols}

Total soluble phenols were spectrophotometrically assayed at $765 \mathrm{~nm}$ using Folin-Ciocalteu reagent according to the method described by Slinkard and Singleton (1977) with minor modifications (Ribera et al., 2013). Total phenol concentration was calculated using chlorogenic acid as a phenolic compound standard.

\section{Antioxidant Enzyme Assays}

SOD (EC. 1.15.1.1), catalase (CAT; EC. 1.11.1.6), peroxidase (POD; EC. 1.11.1.7), and APX (EC. 1.11.1.11) enzyme activities were evaluated from frozen samples stored at $-80^{\circ} \mathrm{C}$. Plant material was ground in liquid nitrogen and macerated in $50 \mathrm{mM}$ potassium phosphate buffer $\left(\mathrm{K}_{2} \mathrm{HPO}_{4}-\mathrm{KH}_{2} \mathrm{PO}_{4} ; \mathrm{pH} 7.0\right)$. The homogenate was centrifuged at $11,000 \times g$ for $15 \mathrm{~min}$ at $4^{\circ} \mathrm{C}$, and the supernatant was used for assay of enzyme activities.
SOD, CAT, APX, and POD activities were calculated on a protein basis. The protein content in the extracts was measured spectrophotometrically using the method described by Bradford (1976), with bovine serum albumin (BSA) used as a standard.

Superoxide dismutase activity was analyzed by measuring inhibition of the photochemical reduction of nitroblue tetrazolium (NBT). The reaction mixture contained $400 \mu \mathrm{L}$ of $0.1 \mathrm{M}$ potassium phosphate buffer $\mathrm{pH} 7.0,10 \mu \mathrm{L}$ of $10 \mathrm{mM}$ ethylenediaminetetraacetic acid (EDTA), $50 \mu \mathrm{L}$ of $260 \mathrm{mM}$ methionine, $80 \mu \mathrm{L}$ of $4.2 \mathrm{mM}$ NBT, $170 \mu \mathrm{L}$ of $130 \mu \mathrm{M}$ riboflavin, and $300 \mu \mathrm{L}$ of enzyme extract. The reaction tubes were illuminated for $15 \mathrm{~min}$ and the absorbance of samples was measured at $560 \mathrm{~nm}$. Non-illuminated and illuminated reactions without enzyme extract were used as controls. One SOD unit was defined as the amount of enzyme corresponding to 50\% inhibition of NBT reduction (Donahue et al., 1997).

Catalase (CAT; EC. 1.11.1.6) activity was measured by monitoring the decomposition of hydrogen peroxide $\left(\mathrm{H}_{2} \mathrm{O}_{2}\right)$ at $240 \mathrm{~nm}$ for $120 \mathrm{~s}$. A $10-\mu \mathrm{L}$ aliquot of enzyme extract was added to a reaction mixture containing $1 \mathrm{~mL}$ of extraction buffer and $3 \mu \mathrm{L}$ of $\mathrm{H}_{2} \mathrm{O}_{2}(30 \% \mathrm{v} / \mathrm{v})$. The enzyme activity was calculated using a molar extinction coefficient of $39.4 \mathrm{mM}^{-1} \mathrm{~cm}^{-1}$ (Pinhero et al., 1997).

Peroxidase (POD; EC. 1.11.1.7) activity was determined by estimating the formation of tetraguaiacol at $470 \mathrm{~nm}$ during $1 \mathrm{~min}$. A $15-\mu \mathrm{L}$ volume of enzyme extract was added to a reaction mixture containing $1 \mathrm{~mL}$ of extraction buffer, $5 \mu \mathrm{L}$ of $\mathrm{H}_{2} \mathrm{O}_{2}$ $(30 \% \mathrm{v} / \mathrm{v})$, and $5 \mu \mathrm{L}$ of guaiacol. A molar extinction coefficient of $26.6 \mathrm{mM}^{-1} \mathrm{~cm}^{-1}$ was used to calculate the enzymatic activity (Pinhero et al., 1997).

Ascorbate peroxidase (EC. 1.11.1.11) activity was assayed according to the method described by Nakano and Asada (1981), by measuring ascorbate decomposition at $290 \mathrm{~nm}$ for $1 \mathrm{~min}$. The coarse extract $(40 \mu \mathrm{L})$ was diluted in a reaction mixture containing $1 \mathrm{~mL}$ of extraction buffer, $5 \mu \mathrm{L}$ of $\mathrm{H}_{2} \mathrm{O}_{2}(30 \% \mathrm{v} / \mathrm{v})$, and $40 \mu \mathrm{L}$ of $10 \mathrm{mM}$ ascorbic acid. Enzyme activity was calculated using a molar extinction coefficient of $2.8 \mathrm{mM}^{-1} \mathrm{~cm}^{-1}$.

\section{Gene Expression Analyses}

Ryegrass tissues were subjected to RNA extraction using a NucleoSpin $^{\circledR}$ RNA Plant Kit (Macherey-Nagel GmbH and Co., KG, Düren, Germany). First-strand cDNA was synthesized from $1 \mu \mathrm{g}$ of total RNA using an AffinityScript qPCR cDNA Synthesis Kit (Stratagene, Cedar Creek, TX, USA) following the manufacturer's recommendations. Quantitative real-time polymerase chain (qRT-PCR) reactions were conducted in order to determinate the expression patterns of Si transporter genes (Lsi1 and Lsi2) in roots, as well as those of three SOD isoform genes ( $\mathrm{Cu} / \mathrm{ZnSOD}, \mathrm{Fe}-\mathrm{SOD}$, and $\mathrm{Mn}$-SOD) in shoots and roots. All qRT-PCR reactions were performed using Brilliant II SYBR Green qPCR Master mix (Stratagene, Cedar Creek, TX, USA) in an ABI 7300 Real-Time PCR System (Applied Biosystems, Foster City, CA, USA). Cycling conditions were $95^{\circ} \mathrm{C}$ for $10 \mathrm{~min}$, followed by 40 cycles at $95^{\circ} \mathrm{C}$ for $30 \mathrm{~s}, 60^{\circ} \mathrm{C}$ for $1 \mathrm{~min}$, and $72^{\circ} \mathrm{C}$ for $30 \mathrm{~s}$. The specific primers used in this study are shown in Table 1. The primer sets used for LpLsil (GenBank accession number KY315994) and LpLsi2 (GenBank accession 
TABLE 1 | List of primers sequences used for quantitative real-time polymerase chain reaction (qRT-PCR) analysis of Si transporters and SOD isoforms genes.

\begin{tabular}{|c|c|c|}
\hline Gene name* & Forward primer $\left(5^{\prime}->3^{\prime}\right)$ & Reverse primer $\left(5^{\prime}->3^{\prime}\right)$ \\
\hline Lsi1 & ACGCCCAGCATGTACTACAAC & TCATGAACACCAGCAGGAAC \\
\hline Lsi2 & CTCTGCATGTACTGGAAGGAC & GTTGAGAGGGTTGAGAGTGTG \\
\hline Fe-SOD & GTTGCCAAGGGAAATCCTGAACCA & AACCCCAGCCGTITATCTTCAAGC \\
\hline $\mathrm{Cu} / \mathrm{Zn}-\mathrm{SOD}$ & GTGTTGCTCCCATCAATGTTGT & CCTGCCAAGATCATCAGCATC \\
\hline Mn-SOD & AATACGAAAATGTGGCTGTGTG & AAAATCTGCATTGTGCATTACG \\
\hline Actin & CCTITTCCAGCCATCTITCA & GAGGTCCTTCCTGATGTCCA \\
\hline eEF1A (m) & GGCTGATTGTGCTGTGCTTA & CTCACTCCAAGGGTGAAAGC \\
\hline
\end{tabular}

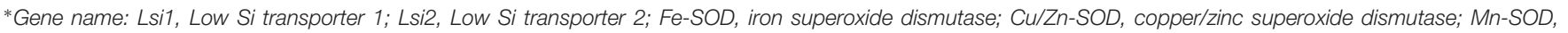
manganese superoxide dismutase; Actin, Actin; eEF1A(m), Eukaryotic elongation factor 1 alpha. Actin or eEF1A(m) were used as housekeeping genes.

number KY315995) were designed using the Primer3 (v. 0.4.0) and primer BLAST tools. Primers sequences for $L p C u / Z n S O D$, $L p F e-S O D$, and $L p M n-S O D$ were obtained from Ribera et al. (2013). Housekeeping genes, LpActin or LpeEF1A (m), were used as internal controls (Ribera et al., 2013). All the experiments were performed using three biological replicates, each with three technical replicates.

\section{Detection of $\mathrm{H}_{2} \mathrm{O}_{2}$ Production by Flow Cytometry}

Suspensions of shoot protoplasts were obtained using the method described by Okuno and Furusawa (1977). The protoplasts were centrifuged at $2,500 \times g$ for $5 \mathrm{~min}$ at $4^{\circ} \mathrm{C}$ and incubated with the fluorescent probe $2^{\prime}, 7^{\prime}$-dichlorodihydrofluorescein diacetate $\left(\mathrm{H}_{2}\right.$ DCFDA) to detect intracellular $\mathrm{H}_{2} \mathrm{O}_{2}$ using the method described by Maxwell et al. (1999) with modifications. $\mathrm{H}_{2} \mathrm{O}_{2}$ production was analyzed using flow cytometry (BD FACS Canto IISN: V96101286; Becton Dickinson, USA). All measurements were performed using an Ar ion laser excited at $488 \mathrm{~nm}$ and emitting at $530 \mathrm{~nm}$. The images were processed through the BD FACSDivaTM, v 6.0 program. A positive control (intact protoplasts plus $100 \mu \mathrm{M} \mathrm{H}_{2} \mathrm{O}_{2}$ ) and negative control (suspension of intact protoplasts without $\mathrm{H}_{2} \mathrm{O}_{2}$ ) were used.

\section{Confocal Microscopy}

A profile of $\mathrm{H}_{2} \mathrm{O}_{2}$ generation in protoplast extracts was also examined by Laser Scanning Confocal Microscopy (CLSM). $\mathrm{H}_{2}$ DCFDA fluorescence emission was recorded at excitation/emission of $488 / 530 \mathrm{~nm}$, and chlorophyll autofluorescence was measured at $633 \mathrm{~nm}$ laser excitation and emission of $750 \mathrm{~nm}$. The images were processed using Image Processing software (software FV10-ASW v.0.2c; Arquimed).

\section{Statistical Analysis}

Experimental data were analyzed using an analysis of variance (ANOVA) following normality and homoscedasticity tests. Differences among means were separated using the Tukey test at the 0.05 probability level. In addition, the relationship between two response variables was investigated by Pearson correlation.

\section{RESULTS}

\section{Concentrations of $\mathrm{Al}$ and $\mathrm{Si}$ in Plants and Dry Matter Production}

Aluminum treatment mostly increased $\mathrm{Al}$ concentration in roots, whereas significantly lower amounts of $\mathrm{Al}$ accumulated in the shoots (Table 2). However, increasing Si doses gradually decreased shoot and root $\mathrm{Al}$ concentrations by up to 49 and $56 \%$, respectively, in Al-treated plants (Table 2). Interestingly, a negative correlation between $\mathrm{Si}$ concentration and $\mathrm{Al}$ concentration was observed in shoots $(r=0.927, p \leq 0.01)$ and roots $(r=0.935, p \leq 0.01)$ of ryegrass grown with $\mathrm{Al}$ and $\mathrm{Si}$ (Table 3). In addition, the $\mathrm{Si}$ concentration of ryegrass tissues steadily increased with an increase in Si dose, but this increment was less noticeable when plants were simultaneously supplied

TABLE 2 | Concentration of $\mathrm{Al}$ and $\mathrm{Si}$, and dry matter production of ryegrass plants hydroponically cultivated under different $\mathrm{Al}$ and $\mathrm{Si}$ treatments.

\begin{tabular}{|c|c|c|c|c|c|c|}
\hline \multirow[t]{2}{*}{ Treatment (mM) } & \multicolumn{2}{|c|}{ Al concentration ( $\left.\mathrm{g} \mathrm{kg}^{-1} \mathrm{DW}\right)$} & \multicolumn{2}{|c|}{ Si concentration ( $\mathrm{g} \mathrm{kg}^{-1} \mathrm{DW}$ ) } & \multicolumn{2}{|c|}{ Dry weight (g) } \\
\hline & Shoots & Roots & Shoots & Roots & Shoots & Roots \\
\hline O Al-O Si & $0.02 \pm 0.00 \mathrm{~cd}$ & $0.16 \pm 0.02 d$ & $0.31 \pm 0.09 e$ & $0.33 \pm 0.03 e$ & $6.53 \pm 0.29 \mathrm{bc}$ & $1.37 \pm 0.06 \mathrm{ab}$ \\
\hline $0 \mathrm{Al}-0.5 \mathrm{Si}$ & $0.01 \pm 0.00 d$ & $0.15 \pm 0.00 d$ & $5.85 \pm 0.44 c$ & $6.42 \pm 0.20 c$ & $7.04 \pm 0.29 a b c$ & $1.37 \pm 0.10 \mathrm{ab}$ \\
\hline $0 \mathrm{Al}-2 \mathrm{Si}$ & $0.01 \pm 0.00 d$ & $0.13 \pm 0.01 d$ & $13.78 \pm 0.26 a$ & $13.47 \pm 0.09 a$ & $6.69 \pm 0.22 \mathrm{abc}$ & $1.39 \pm 0.13 a$ \\
\hline $0.2 \mathrm{Al}-0 \mathrm{Si}$ & $0.07 \pm 0.00 a$ & $3.84 \pm 0.24 a$ & $0.21 \pm 0.03 e$ & $0.38 \pm 0.10 e$ & $6.07 \pm 0.42 c$ & $0.98 \pm 0.06 b$ \\
\hline $0.2 \mathrm{Al}-0.5 \mathrm{Si}$ & $0.04 \pm 0.00 b$ & $2.68 \pm 0.10 b$ & $4.40 \pm 0.13 d$ & $4.30 \pm 0.15 d$ & $7.95 \pm 0.42 a b$ & $1.48 \pm 0.08 a$ \\
\hline $0.2 \mathrm{Al}-2 \mathrm{Si}$ & $0.03 \pm 0.00 \mathrm{bc}$ & $1.69 \pm 0.11 c$ & $10.29 \pm 0.19 b$ & $11.88 \pm 0.20 b$ & $8.09 \pm 0.32 a$ & $1.61 \pm 0.06 a$ \\
\hline
\end{tabular}

Values are means \pm standard error of three replicates. Different letters indicate statistically significant differences $(p \leq 0.05)$ among treatments. 
TABLE 3 | Pearson's correlation among plant growth, chemical and biochemical parameters of ryegrass hydroponically cultivated under different Al and Si treatments.

\begin{tabular}{|c|c|c|c|c|c|c|c|c|c|}
\hline & Al & Si & Dry weight & TBARS & Total phenols & SOD & CAT & POD & APX \\
\hline \multicolumn{10}{|l|}{ Shoots } \\
\hline $\mathrm{Al}$ & 1.00 & & & & & & & & \\
\hline $\mathrm{Si}$ & $-0.927^{* *}$ & 1.00 & & & & & & & \\
\hline Dry weight & $-0.849^{* *}$ & $0.721^{*}$ & 1.00 & & & & & & \\
\hline TBARS & $0.946^{* *}$ & $-0.947^{* *}$ & $-0.757^{*}$ & 1.00 & & & & & \\
\hline Total phenols & $-0.904^{* *}$ & $0.859^{* *}$ & $0.756^{*}$ & $-0.813^{* *}$ & 1.00 & & & & \\
\hline SOD & $0.693^{*}$ & $-0.827^{* *}$ & -0.432 & 0.646 & $-0.721^{*}$ & 1.00 & & & \\
\hline CAT & -0.099 & 0.076 & -0.118 & -0.023 & 0.418 & -0.110 & 1.00 & & \\
\hline POD & $0.863^{* *}$ & $-0.776^{*}$ & $-0.781^{*}$ & $0.715^{*}$ & $-0.932 * *$ & 0.666 & -0.275 & 1.00 & \\
\hline APX & $0.823^{* *}$ & -0.599 & $-0.745^{*}$ & 0.657 & $-0.744^{*}$ & 0.489 & -0.073 & $0.836^{* *}$ & 1.00 \\
\hline \multicolumn{10}{|l|}{ Roots } \\
\hline $\mathrm{Al}$ & 1.00 & & & & & & & & \\
\hline $\mathrm{Si}$ & $-0.935^{* *}$ & 1.00 & & & & & & & \\
\hline Dry weight & $-0.876^{* *}$ & $0.823^{* *}$ & 1.00 & & & & & & \\
\hline TBARS & $0.740^{*}$ & $-0.734^{*}$ & $-0.800^{* *}$ & 1.00 & & & & & \\
\hline Total phenols & $-0.825^{* *}$ & $0.741^{*}$ & $0.706^{*}$ & -0.523 & 1.00 & & & & \\
\hline SOD & $0.883^{* *}$ & $-0.961^{* *}$ & $-0.778^{*}$ & $0.787^{*}$ & $-0.731^{*}$ & 1.00 & & & \\
\hline CAT & $-0.691^{*}$ & $0.838^{* *}$ & 0.524 & -0.399 & $0.738^{*}$ & $-0.795^{*}$ & 1.00 & & \\
\hline POD & $-0.796^{*}$ & $0.925^{* *}$ & 0.666 & -0.509 & $0.690^{*}$ & $-0.858^{* *}$ & $0.956^{* *}$ & 1.00 & \\
\hline APX & $-0.925^{* *}$ & $0.980^{* *}$ & $0.806^{* *}$ & -0.666 & $0.800^{* *}$ & $-0.930^{* *}$ & $0.894^{* *}$ & $0.962^{* *}$ & 1.00 \\
\hline
\end{tabular}

Asterisks indicate significance as follows: ${ }^{* *} p \leq 0.01,{ }^{*} p \leq 0.05$.

with $\mathrm{Al}$ and $\mathrm{Si}$ (Table 2). Of the total amount of Si taken up by plants, over $80 \%$ accumulated in the shoots.

No changes in shoot growth were observed in plants treated with $\mathrm{Al}$ alone, whereas root dry matter production was reduced by approximately $28.5 \%$. Silicon treatments did not affect ryegrass growth when $\mathrm{Si}$ was applied to plants cultivated without $\mathrm{Al}$ (Table 2). However, root yield was improved by at least $51 \%$ when Si was applied to Al-treated plants. Moreover, a positive correlation $(r=0.823, p \leq 0.01)$ between $\mathrm{Si}$ concentration and dry weight was observed for the roots of Al-treated plants supplied with increasing concentrations of Si (Table 3).

\section{Analysis of Si Transporter Gene Expression in Response to Al Toxicity}

The relative expression of two putative $\mathrm{Si}$ transporter genes (LpLsi1 and LpLsi2) in roots was assessed in ryegrass subjected to different $\mathrm{Al}$ and $\mathrm{Si}$ supplementation. In plants grown without Al, the expression level of LpLsi1 and LpLsi2 was down-regulated by approximately 4.2 - and 2.8 -fold, respectively, in response to $\mathrm{Si}$ addition to the growth media (Figures 1A,B). A similar expression pattern was observed when Al was applied alone, with the expression levels of LpLsi1 and LpLsi2 being reduced by approximately 7.1- and 2.9-fold, respectively (Figures 1A,B). However, when $\mathrm{Al}$ was added in combination with $\mathrm{Si}$, the expression level of these $\mathrm{Si}$ transporters was significantly enhanced (Figures 1A,B). The highest $\mathrm{Si}$ dose applied to Al-treated plants increased the expression level of LpLsi1 by approximately 5.4-fold (Figure 1A), whereas that of LpLsi2 was up-regulated by at least 2.5-fold irrespective of Si dosage (Figure 1B).

\section{Lipid Peroxidation}

The addition of $0.2 \mathrm{mM} \mathrm{Al}$ increased root lipid peroxidation by approximately 29\% (Figure 2B); however, no differences in oxidative damage were observed in shoots as a consequence of Al supply (Figure 2A). Likewise, no significant changes in TBARS accumulation were observed among plants grown with only Si (Figures 2A,B). However, Si at the highest concentration supplied diminished lipid peroxidation in Al-treated plants by approximately 32.6 and $27.7 \%$ in shoots and roots, respectively (Figures 2A,B). Consequently, lipid peroxidation was negatively correlated with Si concentration in shoots $(r=-0.947, p \leq 0.01)$ and roots $(r=-0.734, p \leq 0.05)$, as shown in Table 3 .

\section{Plant Antioxidant Responses}

Plants treated with $\mathrm{Al}$ showed an evident increment in total phenols (Figures 3A,B). A significant increase in total phenol concentration was also observed in the shoots and roots of ryegrass treated with the highest $\mathrm{Si}$ dose, with a further increase being observed in plants treated with both $\mathrm{Al}$ and $\mathrm{Si}$ (Figures 3A,B).

In order to investigate the effect of $\mathrm{Si}$ on the ROS scavenging enzyme system under $\mathrm{Al}$ stress conditions, the activities of SOD, CAT, POD, and APX enzymes were evaluated (Figures 4A-H). Aluminum supplied alone significantly increased SOD activity by approximately $37.2 \%$ in shoots and $27.5 \%$ in roots (Figures $\mathbf{4 A}, \mathbf{B}$ ). Likewise, the highest Si dose activated SOD enzyme in non-Al-treated plants (Figures 4A,B). However, when $\mathrm{Al}$ and $\mathrm{Si}$ were simultaneously applied, SOD activity was significantly reduced by 20.08 and $43.8 \%$ in shoots and roots, respectively (Figures $4 A, B$ ). 


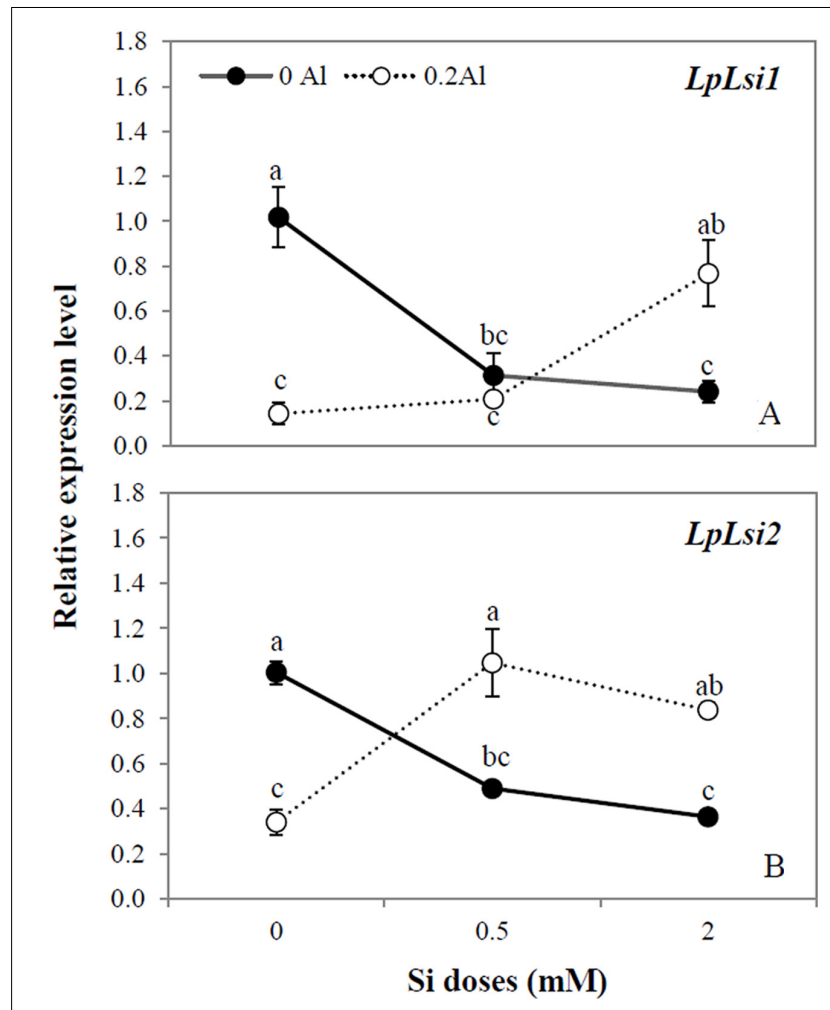

FIGURE 1 | Expression analysis of $L$ pLsi1 (A) and $L p L s i 2$ (B) genes determined by qRT-PCR in roots of ryegrass hydroponically cultivated under $\mathrm{Al}$ and $\mathrm{Si}$ treatments. The expression levels were normalized in relation to Actin or eEF1A $(m)$ gene expression. Data are means of three replicates @ standard error. Different letters indicate statistically significant differences $(p \leq 0.05)$ among treatments.

The application of $\mathrm{Al}$ alone increased CAT activity in shoots and roots by at least 4.2- and 4.7-fold, respectively (Figures 4C,D). In plants grown in the absence of Al, Si enhanced CAT activity by approximately 3.0-fold (shoots) and 5.8-fold (roots) (Figures 4C,D). Plants supplied with $\mathrm{Al}+\mathrm{Si}$ did not show significant differences in CAT activity compared with those supplied with $\mathrm{Al}$ alone, the exception being in the roots of plants supplied with the highest $\mathrm{Si}$ dose, which exhibited an approximate 60\% increase (Figures 4C,D).

Shoot POD activity increased by approximately $30 \%$ in Altreated plants compared with non-treated plants, although no significant changes were observed in roots (Figures $4 \mathrm{E}, \mathrm{F}$ ). The addition of Si augmented POD activity in plants grown without $\mathrm{Al}$ (Figures 4E,F). This effect was most evident in roots, in which the activity of this enzyme was increased by 2.1 -fold at the highest Si supply (Figure 4F). Likewise, root POD was activated by approximately 1.7-fold under combined $\mathrm{Al}$ and $\mathrm{Si}$ treatments (Figure 4F), whereas in shoots the enzyme activity was diminished (Figure 4E).

Addition of Al to the growth media considerably increased APX activity by approximately 2.7 -fold and 1.8 -fold in shoots and roots, respectively (Figures 4G,H). Similarly, Si application elevated APX activity in ryegrass (Figures $\mathbf{4 G}, \mathbf{H}$ ), and this effect was enhanced by 2.2 -fold in the roots of plants receiving the combined Al-Si treatments (Figure $4 \mathbf{H}$ ). Conversely, Si supply decreased shoot APX activity by approximately $25.9 \%$ in Al-treated plants (Figure 4G).

The changes in antioxidant responses of Al-stressed plants as a consequence of Si uptake were additionally examined by means of Pearson correlation as shown in the Table 3. Briefly, we found a negative correlation between Si concentration and SOD activity in shoots $(r=-0.827, p \leq 0.01)$ and roots $(r=-0.961, p \leq 0.01)$. Conversely, for roots, we observed positive relationships between Si concentration and either total phenols $(r=0.741, p \leq 0.05)$ or the antioxidant enzymes of the second line of defense (CAT, $r=0.838, p \leq 0.01$; POD $, r=0.925, p \leq 0.01$; APX, $r=0.980$, $p \leq 0.01)$.

\section{Analysis of SOD Isoform Gene Expression in Response to $\mathrm{Al}$ and $\mathrm{Si}$ Treatments}

Genes of SOD isoforms (Fe-SOD, Cu/Zn-SOD, and Mn-SOD) were differentially expressed as a consequence of $\mathrm{Si}$ and $\mathrm{Al}$ supply (Figures 5A-F). Aluminum supplied alone reduced the gene expression of Fe-SOD and $\mathrm{Cu} / \mathrm{Zn}$-SOD in shoots (Figures 5A,C), whereas no changes in the expression pattern of these genes was

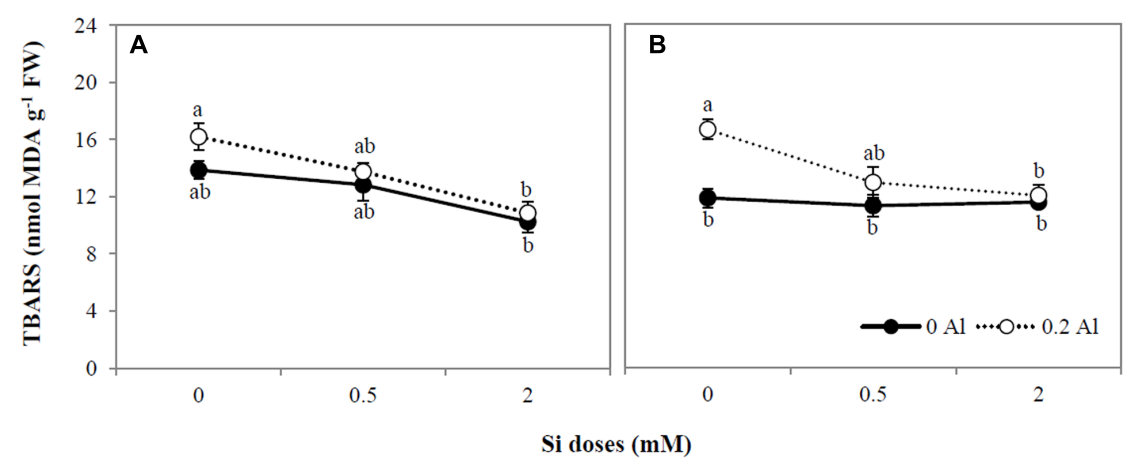

FIGURE 2 | Lipid peroxidation in shoot (A) and root $\mathbf{( B )}$ of ryegrass hydroponically cultivated under Al and Si treatments. Data are means of three replicates \pm standard error. Different letters indicate statistically significant differences $(p \leq 0.05)$ among treatments. 


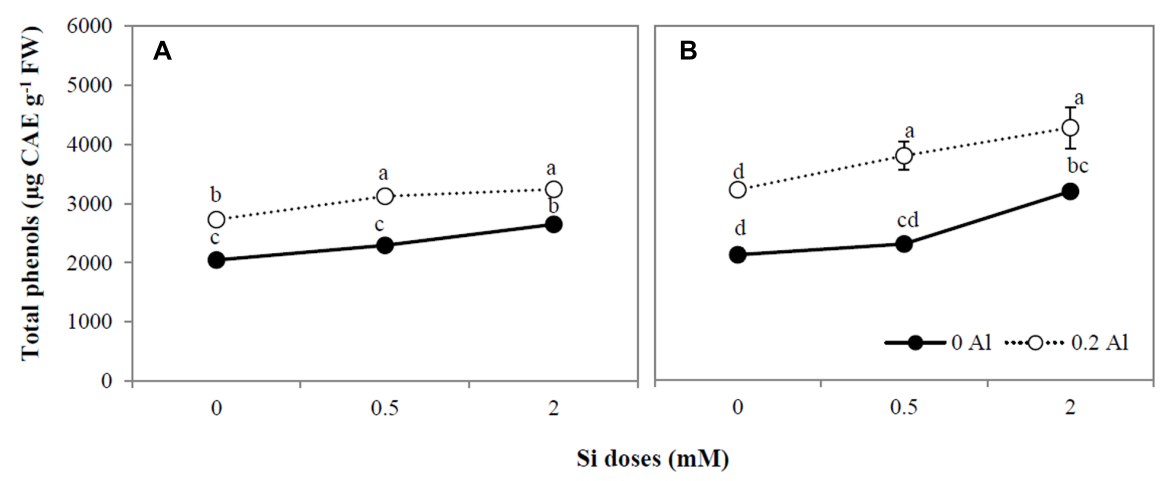

FIGURE 3 | Total phenol concentration in shoot (A) and root (B) of ryegrass hydroponically cultivated under Al and Si treatments. Data are means of three replicates \pm standard error. Different letters indicate statistically significant differences $(p \leq 0.05)$ among treatments.

detected in the roots (Figures 5B,D). In addition, expression of the Mn-SOD gene was up-regulated by approximately 1.7 -fold in shoots and roots exposed to $\mathrm{Al}$ (Figures 5E,F). Increasing $\mathrm{Si}$ doses lowered the gene expression of Fe-SOD by up to 1.9 -fold in the shoots and 2.2-fold in the roots of plants cultivated without $\mathrm{Al}$ (Figures 5A,B), whereas the transcript levels of Mn-SOD were enhanced in shoots by approximately 1.7-fold by $\mathrm{Si}$ addition (Figure $5 \mathrm{E}$ ). In contrast, in plants receiving $\mathrm{Si}$ alone, there was no significant changes in the expression level of either shoot $\mathrm{Cu} / \mathrm{Zn}$-SOD or root Mn-SOD genes (Figures $\mathbf{5 C , F}$ ). However, in roots, $\mathrm{Cu} / \mathrm{Zn}-\mathrm{SOD}$ was down-regulated by at least 1.8-fold as a consequence of $\mathrm{Si}$ supply (Figure 5D). In plants simultaneously exposed to $\mathrm{Al}$ and $\mathrm{Si}$, the addition of $\mathrm{Si}$ did not induce significant changes in the expression level of Fe-SOD in shoots and roots (Figures 5A,B). Although a similar expression pattern of $\mathrm{Cu} / \mathrm{Zn}$-SOD was observed in the shoots of Al-treated plants under the different Si treatments (Figure 5C), the gene expression of this enzyme was down-regulated by up to 1.9 -fold in roots (Figure 5D). Likewise, $\mathrm{Si}$ application to Al-treated plants significantly reduced the transcript level of Mn-SOD by at least 2.2- and 3.8-fold in shoots and roots, respectively (Figures 5E,F).

\section{Hydrogen Peroxide Production in Shoot Protoplasts Exposed to $\mathrm{Al}$ and $\mathrm{Si}$}

Aluminum treatment augmented $\mathrm{H}_{2} \mathrm{O}_{2}$ generation by approximately $38 \%$ in shoot protoplasts (Figure 6A). A progressive increase in $\mathrm{H}_{2} \mathrm{O}_{2}$ production was also observed when $\mathrm{Si}$ was added alone, and the accumulation of $\mathrm{H}_{2} \mathrm{O}_{2}$ was enhanced to an even greater extent in plants simultaneously supplied with $\mathrm{Si}$ and $\mathrm{Al}$ (Figure 6A). This pattern was consistent with the observations made by CLSM analysis (Figure 6B), which revealed a progressive increase in the fluorescence of an $\mathrm{H}_{2}$ DCFDA probe generated by $\mathrm{Si}$ and $\mathrm{Al}$ application.

\section{DISCUSSION}

Although several previous studies have reported that Si provide beneficial effects on plants subjected to Al stress, the mechanisms underlying these responses have remained poorly understood. Moreover, only a few studies have examined the effect of Si-mediated amelioration of Al toxicity in terms of the regulation of Al and Si uptake systems (e.g., Britez et al., 2002; Wang et al., 2004; Dorneles et al., 2016) and plant antioxidant performance (e.g., Shahnaz et al., 2011; Shen et al., 2014). Likewise, to date, the effect of $\mathrm{Si}$ on $\mathrm{Al}$ stress in ryegrass, a forage species belonging to Si-accumulator plants (Jarvis, 1987; Nanayakkara et al., 2008), has yet to be addressed.

The high level of toxic $\mathrm{Al}$ in acid soils is an important limiting factor for plant production (Mora et al., 2006). In our study, the exposure of plants to $0.2 \mathrm{mM} \mathrm{Al}$ significantly increased $\mathrm{Al}$ accumulation, mainly in the roots (Table 2), with a consequent reduction of approximately $28.5 \%$ in root dry matter production (Table 2 ). These results are consistent with our previous findings for ryegrass (Cartes et al., 2010), since it is well known that $\mathrm{Al}$ toxicity involves the rapid inhibition of root growth (e.g., Matsumoto, 2000; Kochian et al., 2005; Horst et al., 2010; Singh et al., 2017). The role played by Si in promoting plant growth under Al toxicity has been widely accepted (e.g., Hara et al., 1999; Singh et al., 2011; Shen et al., 2014; Tripathi et al., 2016). Correspondingly, Si application to Al-treated plants significantly reduced the Al concentration in ryegrass (Table 2 ) and improved root dry weight by at least $51 \%$ (Table 2). A slight reduction in Si concentration in plant tissues was also found when plants were simultaneously supplied with $\mathrm{Al}$ and Si (Table 2). Moreover, our results revealed a negative correlation between $\mathrm{Si}$ and $\mathrm{Al}$ uptake in plants treated with $\mathrm{Al}$ and $\mathrm{Si}$, whereas $\mathrm{Si}$ concentration and dry matter production were positively related (Table 3 ). The reduction in $\mathrm{Al}$ and $\mathrm{Si}$ uptake might be attributed to the formation of biologically inactive aluminosilcate (Al-Si) complexes in the growth media, thus lowering Al availability (Barcelo et al., 1993; Baylis et al., 1994; Ma et al., 1997; Cocker et al., 1998a), with the consequent enhancement of root growth. Nevertheless, the formation of Al-Si inside plant tissues could also be involved in the growthpromoting effect of Si under Al stress (Hodson and Sangster, 1993; Cocker et al., 1998b; Wang et al., 2004). Indeed, it has been demonstrated that Al toxicity may be decreased by co-deposition of $\mathrm{Al}$ and $\mathrm{Si}$ in the root epidermal walls of sorghum (Hodson and 

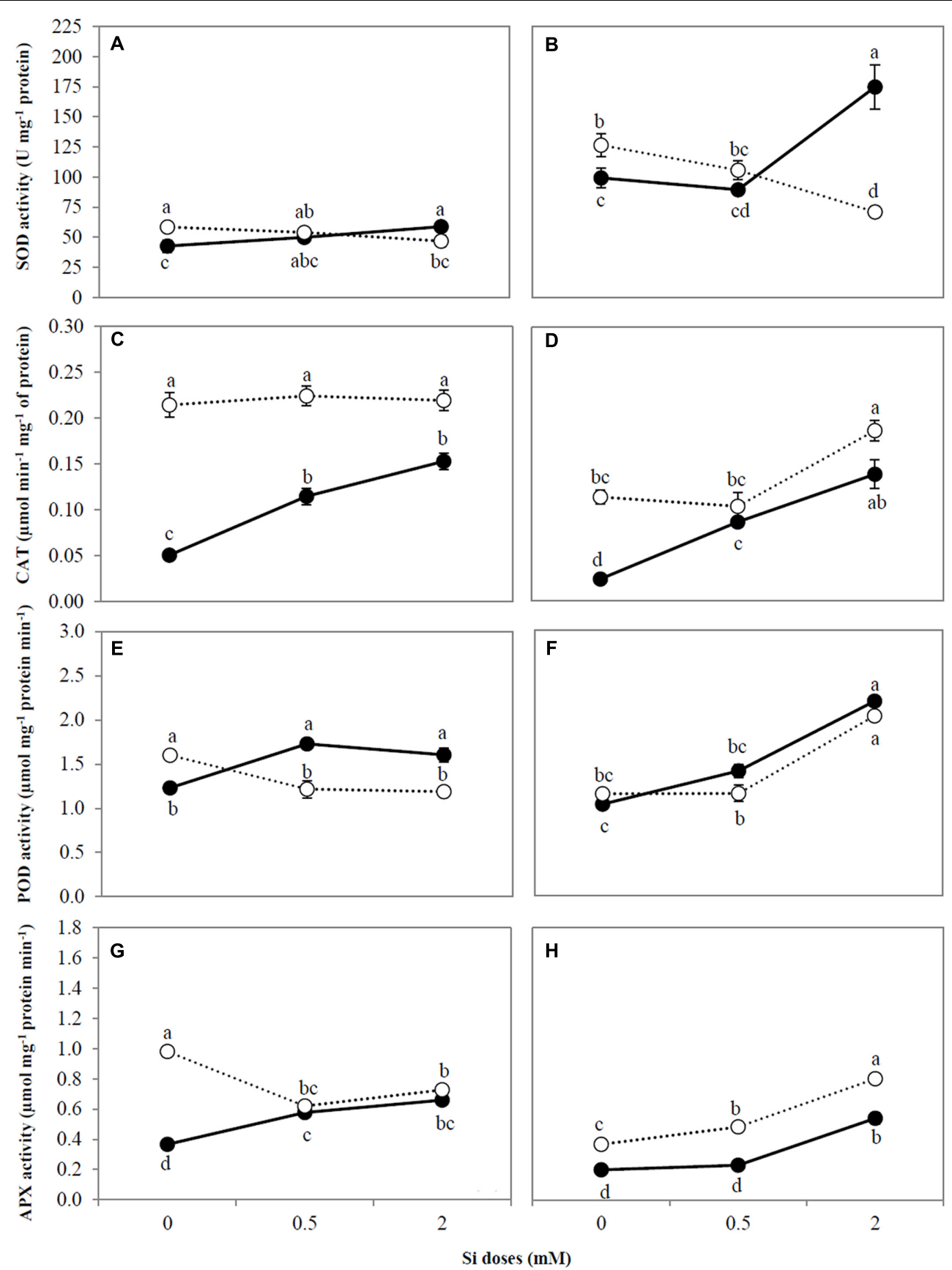

Si doses (mM)

$\rightarrow 0 \mathrm{Al} \quad \cdots \circ \cdots 0.2 \mathrm{Al}$

FIGURE 4 | The activity of antioxidant enzyme SOD (A,B), CAT (C,D), POD (E,F), and APX (G,H) in shoots and roots of ryegrass hydroponically cultivated under $\mathrm{Al}$ and $\mathrm{Si}$ treatments. Data are means of three replicates \pm standard error. Different letters indicate statistically significant differences $(p \leq 0.05)$ among treatments.

Sangster, 1993). Similarly, Cocker et al. (1998b) and Wang et al. (2004) have also suggested that formation of Al-Si complexes in the root apoplast of wheat and maize is a possible mechanism for $\mathrm{Al}$ detoxification in plants.

Although all plants contain $\mathrm{Si}$ in their tissues, the concentration of this element varies greatly among species, in a range from 0.1 to $10 \%$ on a dry weight basis (Epstein, 1999; Ma and Takahashi, 2002), which is indicative of the fact that the benefits of Si to plants grown under stress can also be highly variable. Recent studies have shown that Si accumulation in plants is controlled by influx and efflux Si transporters that could be involved in the differential $\mathrm{Si}$-induced responses to 


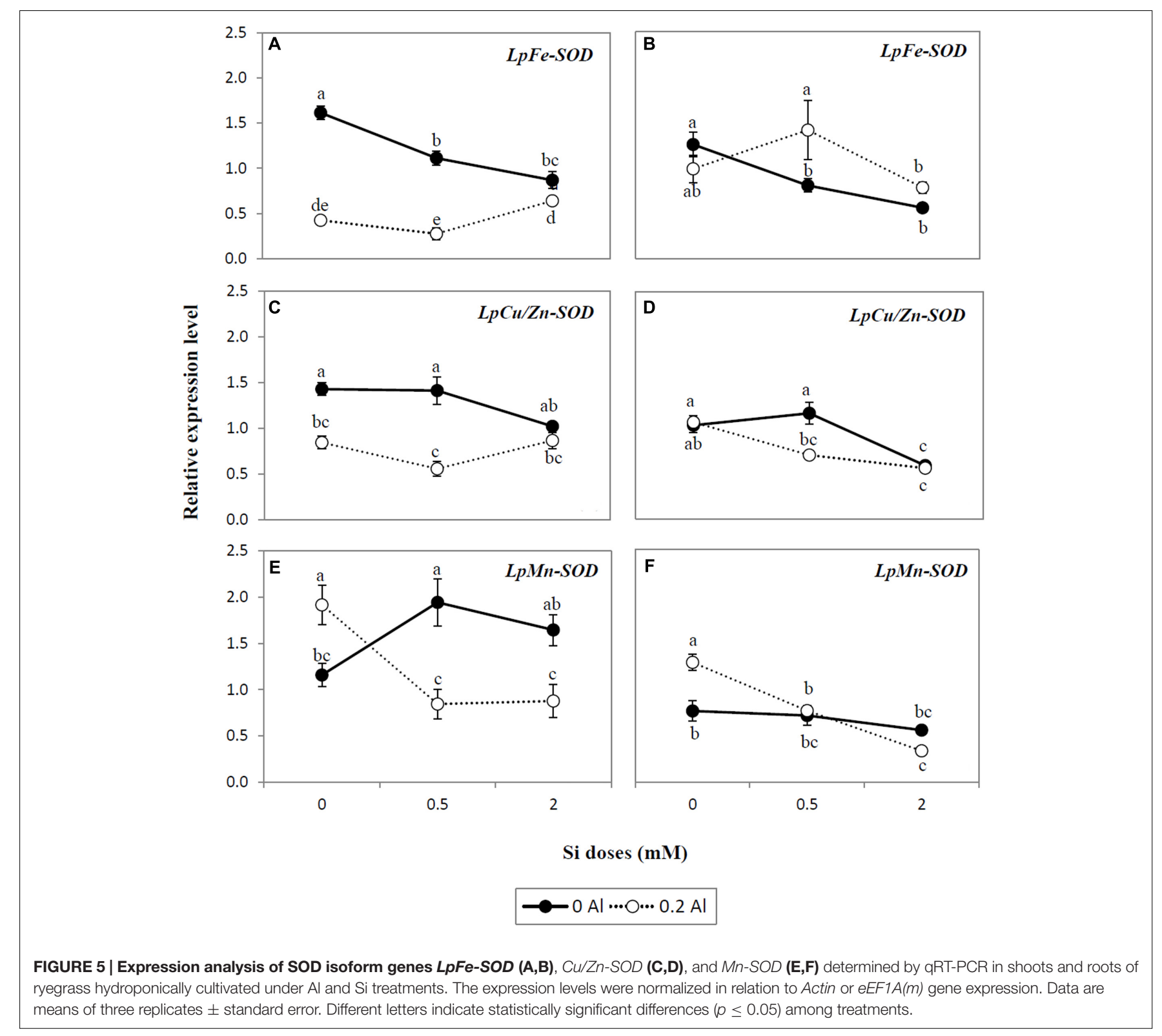

cope with different plant stress (e.g., Ma et al., 2006, 2007; Yamaji et al., 2008, 2012; Chiba et al., 2009; Mitani et al., 2009a,b, 2011a,b; Yamaji and Ma, 2009; Grégoire et al., 2012; Montpetit et al., 2012; Deshmukh et al., 2013; Ma and Yamaji, 2015). To further investigate the effect of Si uptake on ryegrass subjected to $\mathrm{Al}$ stress, we assessed the gene expression of two Si transporters (Lsi1 and Lsi2) in plants with different $\mathrm{Al}$ and Si supply (Figures 1A,B). Lsil is a channel-type transporter belonging to aquaporin Nodulin26-like intrinsic protein (NIP) III subfamily (Ma et al., 2006), whereas Lsi2 is an Si efflux transporter belonging to the family of putative anion transporters (Ma et al., 2007). Efficient coupling of Lsil with Lsi 2 controls the uptake of $\mathrm{Si}$ in species such as rice, barley, and maize (Ma et al., 2006, 2007; Chiba et al., 2009; Mitani et al., 2009a,b). Our study showed that in plants cultivated without
$\mathrm{Al}$, the mRNA expression levels of both LpLsi1 and LpLsi2 were down-regulated in plants supplied with Si (Figures 1A,B). Some studies have shown that the accumulation of Lsi1 mRNA in maize (ZmLsi1), barley (HvLsi1), and wheat (TaLsi1) is not affected by the addition of Si (Chiba et al., 2009; Mitani et al., 2009a; Montpetit et al., 2012). Nevertheless, Ma et al. (2006, 2007) found that the gene expression of both OsLsi1 and OsLsi2 was decreased by approximately $25 \%$ in rice, as a consequence of continuous Si application. A similar expression pattern has been detected for Lsi1 in maize (ZmLsil) (Bokor et al., 2014) as well as for Lsi2 in barley (HvLsi2) (Mitani et al., 2009b) and maize (Bokor et al., 2014). Moreover, a recent study has stated that the Si-induced down-regulation of Si transporter genes is controlled by Si accumulation in the shoots of rice (Mitani et al., 2016). 


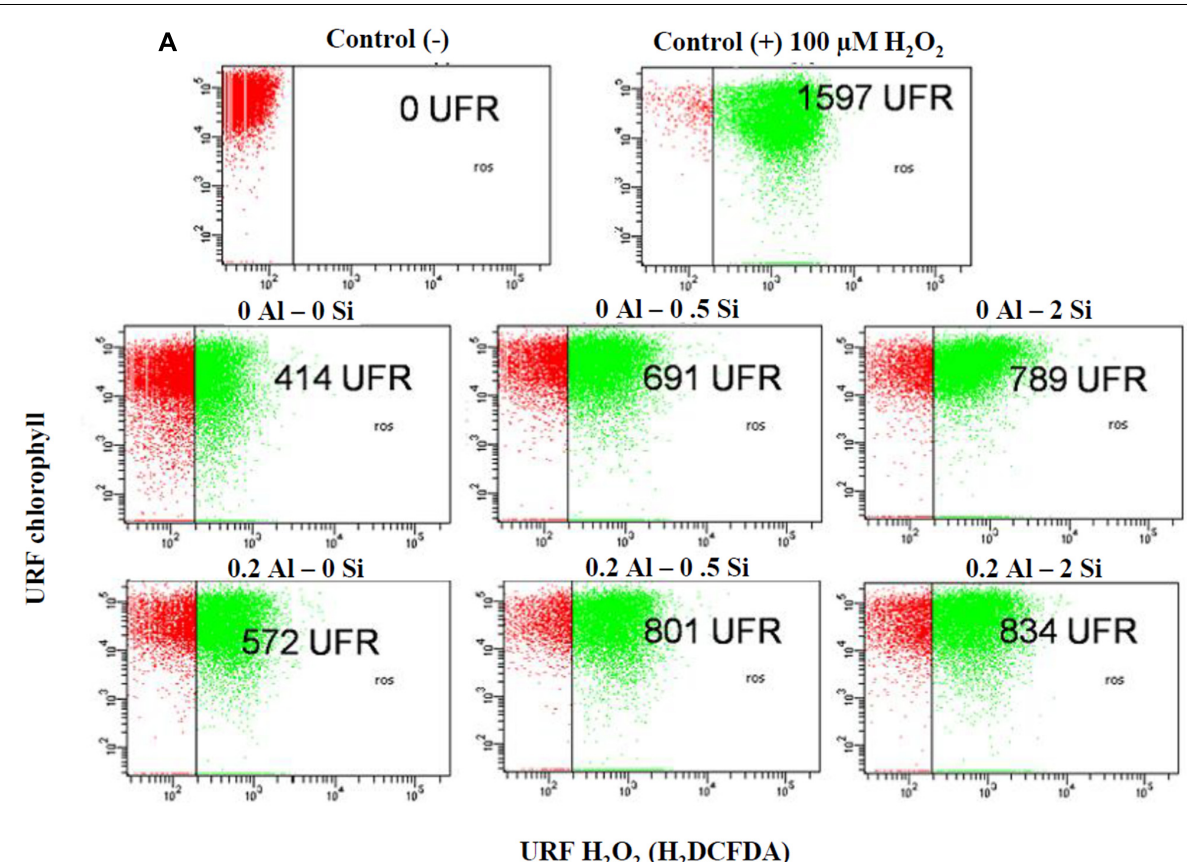

B

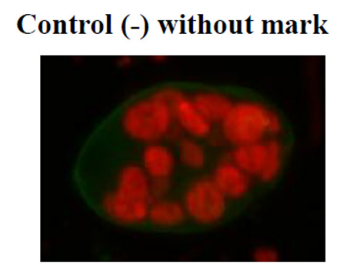

Control (+) $100 \mu \mathrm{M} \mathrm{H}_{2} \mathrm{O}_{2}$
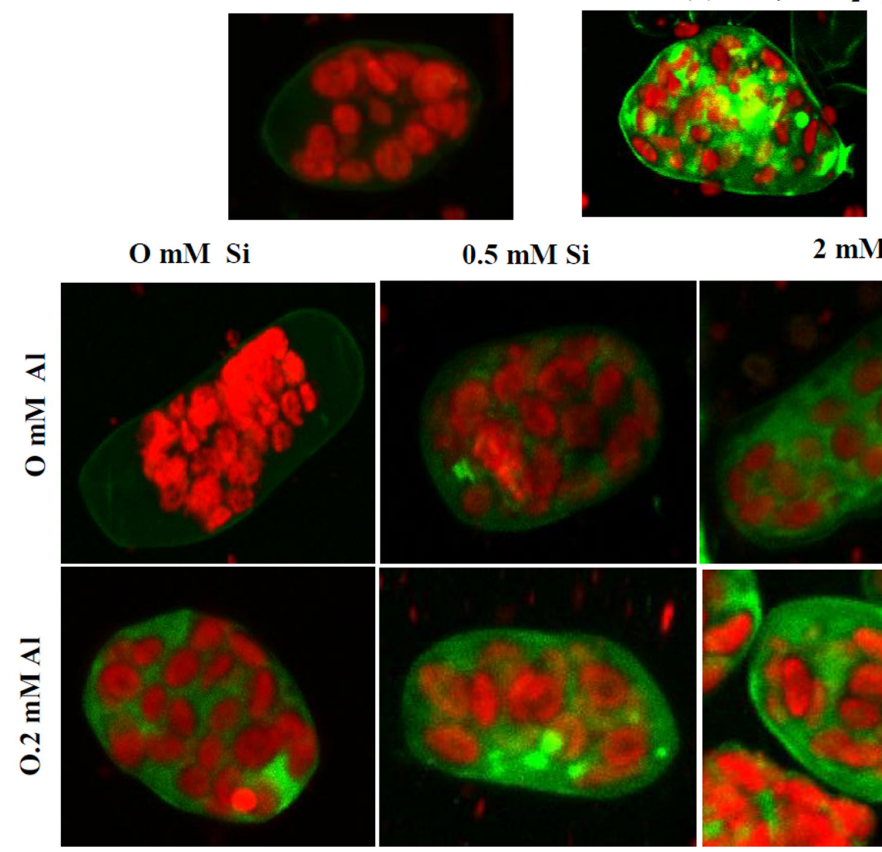

$0.5 \mathrm{mM} \mathrm{Si}$

$2 \mathrm{mM} \mathrm{Si}$
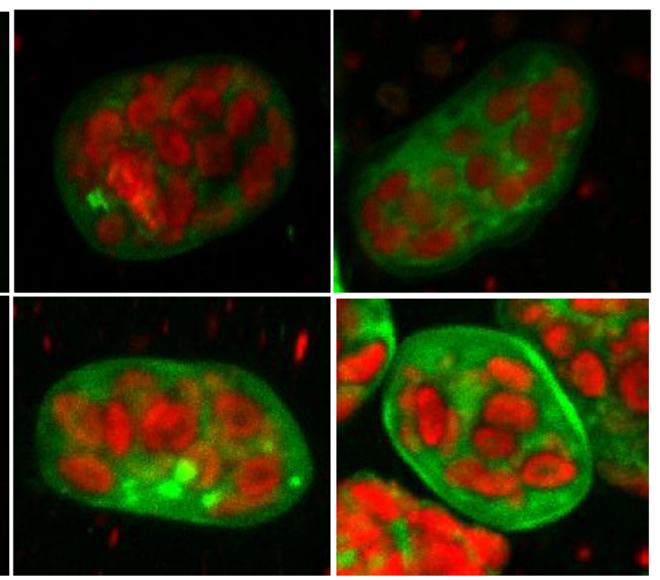

FIGURE 6 | Hydrogen peroxide $\left(\mathrm{H}_{2} \mathrm{O}_{2}\right)$ production in shoot protoplasts of ryegrass hydroponically cultivated under $\mathrm{Al}$ and $\mathrm{Si}$ treatments. (A) Dot plot representation of flow cytometry data. For the positive control, $100 \mu \mathrm{M} \mathrm{H}_{2} \mathrm{O}_{2}$ was used. (B) Confocal projection images showing the increasing concentration of $\mathrm{H}_{2} \mathrm{O}_{2}$. Hydrogen peroxide fluorescence were collected by excitation/emission wave lengths $488 \mathrm{~nm} / 530 \mathrm{~nm}$ by Confocal Laser Scanning Microscope.

At present, there is little information on the effect of any plant stress on the transcriptional regulation of Si transporters genes. Bokor et al. (2014) observed that Si supply downregulated the expression of $Z m L s i 1$ and $Z m L s i 2$ in the roots of maize subjected to excess zinc $(\mathrm{Zn})$. By contrast, it has been reported that $\mathrm{Si}$ increased the expression level of OsLsi1 and OsLsi2 under conditions of cadmium $(\mathrm{Cd})$ and copper $(\mathrm{Cu})$ toxicity in rice plants (Kim et al., 2014). Likewise, Vulavala et al. (2016) found that a putative Si transporter in potato (StLsi1) was up-regulated in response to Si and drought stress. 
Interestingly, we found that the transcript levels of both LpLsi1 and LpLsi2 were significantly down-regulated by Al supply, but up-regulated by 5.4-fold (LpLsi1) and 2.5-fold (LpLsi2) when $\mathrm{Al}$ was added in combination with Si (Figures 1A,B). Compared with plants cultivated with $\mathrm{Si}$ alone, the reduction in $\mathrm{Si}$ concentration in plants simultaneously supplied with $\mathrm{Al}$ and Si (Table 2), could be responsible for the up-regulation of LpLsi1 and LpLsi2 (Figures 1A,B). This behavior might indicate an increased requirement for $\mathrm{Si}$ in ryegrass in order to cope with Al-induced toxicity. Further studies are needed to confirm this assumption.

As a possible alternative mechanism of Si-mediated $\mathrm{Al}$ detoxification in plants, enhancement of the antioxidant defense system has also been proposed (Shahnaz et al., 2011; Shen et al., 2014; Liang et al., 2015; Tripathi et al., 2016). As stated above, $\mathrm{Al}$ toxicity can lead to the generation of reactive oxygen species (ROS), such as superoxide radicals $\left(\mathrm{O}_{2}^{\bullet-}\right)$, hydroxyl radicals $\left({ }^{\bullet} \mathrm{OH}\right)$, and hydrogen peroxide $\left(\mathrm{H}_{2} \mathrm{O}_{2}\right)$ molecules, which cause oxidative damage to plant cells (e.g., Yamamoto et al., 2001, 2002, 2003; Kochian et al., 2005; Singh et al., 2017). In agreement with previous reports (Cartes et al., 2010, 2012), our results show that $0.2 \mathrm{mM} \mathrm{Al}$ increased lipid peroxidation in ryegrass (Figures 2A,B), confirming that oxidative stress occurs under Al supply. Nevertheless, $2 \mathrm{mM}$ Si significantly diminished Al-induced lipid peroxidation by approximately 32 and $28 \%$ in shoots and roots, respectively (Figures $\mathbf{2 A , B}$ ). Moreover, a negative correlation between $\mathrm{Si}$ concentration and lipid peroxidation was detected in Al-treated plants (Table 3). Consistent with our findings, Shen et al. (2014) observed a noticeable decrease in lipid peroxidation attributable to $\mathrm{Si}$ in peanut grown under $\mathrm{Al}$ excess. Similarly, there is increasing evidence showing that oxidative damage to biological membranes decreases as a consequence of Si application to plants subjected to different environmental stresses (e.g., Liang et al., 2003; Zhu et al., 2004; Shi et al., 2005; Gunes et al., 2007, 2008; Li et al., 2012; Khoshgoftarmanesh et al., 2014; Kim et al., 2014; Habibi, 2015; Zia-ur-Rehman et al., 2016).

Whereas Al toxicity enhanced plant phenols concentration (Figures 3A,B) and augmented the activities of antioxidant enzymes (Figures $\mathbf{4 A - H}$ ), Si application induced differential responses in the antioxidant system of Al-stressed plants (Figures 3A,B, 4A-H). It has been suggested that Si may enhance Al tolerance by increasing the production of phenolic compounds with Al-chelating ability (Kidd et al., 2001; Shahnaz et al., 2011). Furthermore, it has been reported that Si uptake by plants subjected to certain stresses can lead to increased production of phenolics with antioxidant and/or structural function (Fleck et al., 2010, 2015; Song et al., 2016). Likewise, enzymes and genes involved in the biosynthesis of either soluble phenolics (e.g., flavonoids) or structural polyphenols (e.g., lignin) have also been shown to be induced by Si (Liang et al., 2007; Shetty et al., 2011; Zhang et al., 2013; Song et al., 2016). Here, we found that Si addition (mainly at the highest dose) increased the total phenol concentration in plants treated with $\mathrm{Al}$ and Si (Figures 3A,B), and that there was a negative relationship between phenols concentration and lipid peroxidation (Table 3). Thus, the enhanced phenols accumulation triggered by Si may have contributed to the amelioration of Al-induced oxidative stress in ryegrass.

Differential changes in the activity of antioxidant enzymes, as a consequence of $\mathrm{Al}$ and Si treatments, were also observed. SOD constitutes the first line of defense in the enzymatic antioxidant responses by catalyzing the dismutation of $\mathrm{O}_{2}{ }^{\bullet-}$ to $\mathrm{H}_{2} \mathrm{O}_{2}$ and $\mathrm{O}_{2}$ (Takahashi and Asada, 1983; Alscher et al., 2002). Our results indicate that the highest $\mathrm{Si}$ dose decreased SOD activity in plants subjected to Al stress (Figures 4A,B), as supported by the negative correlation between SOD activity and Si concentration (Table 3). Likewise, differential gene expression of SOD isoforms occurred in plants exposed to $\mathrm{Al}$ and $\mathrm{Si}$ (Figures 5A-F). The major differences were detected in the roots at the highest $\mathrm{Si}$ level, which induced a significant decrease in expression of the $L p C u / Z n-S O D$ and $L p M n-S O D$ genes in plants grown under Al toxicity (Figures 5D,F). A similar expression pattern was observed for the LPMn-SOD gene in shoots, which was downregulated by at least 2.2-fold in combined Al-Si treatments (Figure 5E). The decrease in either SOD activity (Figures 4A,B) or the gene expression pattern of SOD isoforms (Figures 5A,D,F) coincided with a significant reduction in lipid peroxidation at the highest Si dose (Figures 2A,B), denoting that $2 \mathrm{mM} \mathrm{Si}$ can diminish the requirement for SOD enzyme in Al-treated plants.

It is noteworthy that the antioxidant enzymes responsible for $\mathrm{H}_{2} \mathrm{O}_{2}$ scavenging (CAT, POD, and APX) were activated by $\mathrm{Si}$ in the roots of Al-stressed plants (Figures 4D,F,H). Moreover, a direct correlation between $\mathrm{Si}$ concentration and the activities of CAT, POD, and APX was found in the roots of plants treated with $\mathrm{Al}$ and $\mathrm{Si}$ (Table 3 ). The activation of these enzymes was accompanied by a noticeable decrease in lipid peroxidation (Figures 2A,B), with a consequent reduction in the oxidative damage of biological membranes induced by $\mathrm{Al}$.

We also detected an apparent increase in intracellular $\mathrm{H}_{2} \mathrm{O}_{2}$ production in shoot protoplasts of plants simultaneously supplied with $\mathrm{Al}$ and $\mathrm{Si}$ (Figures 6A,B). It is remarkable that there is so little information available regarding the role of $\mathrm{Si}$ in $\mathrm{H}_{2} \mathrm{O}_{2}$ generation under either biotic or abiotic stress conditions. In this context, the only study that has examined the relationship between $\mathrm{Si}$ and $\mathrm{H}_{2} \mathrm{O}_{2}$ production in plants subjected to Al toxicity (Lima et al., 2016) showed an opposite trend when compared with our results. Nevertheless, under freezing stress, Habibi (2015) detected an increase in $\mathrm{H}_{2} \mathrm{O}_{2}$ levels induced by $\mathrm{Si}$ in pistachio plants, which is consistent with the findings of the present study. This significant increase in $\mathrm{H}_{2} \mathrm{O}_{2}$ production might be related to the reduction in POD activity observed in the shoots of plants simultaneously treated with $\mathrm{Al}$ and $\mathrm{Si}$ (Figure 4E). Indeed, $\mathrm{H}_{2} \mathrm{O}_{2}$ plays a dual role in vascular plants by either inducing oxidative damage or acting as signaling molecule in several physiological processes, including senescence (Peng et al., 2005), photorespiration and photosynthesis (Noctor and Foyer, 1998), and growth and development (Foreman et al., 2003). $\mathrm{H}_{2} \mathrm{O}_{2}$ also functions as a second messenger that modulates the expression of antioxidant enzymes and stress responses (Apel and Hirt, 2004). Accordingly, further work should focus on the mechanisms underlying the $\mathrm{Si}$ modulation of $\mathrm{H}_{2} \mathrm{O}_{2}$ production under Al stress. 
Finally, taken together, our findings provide the first biochemical and molecular evidence that $\mathrm{Si}$ counteracts the negative effects of $\mathrm{Al}$ by modulating $\mathrm{Al}$ and Si uptake as well as enzymatic and non-enzymatic antioxidant responses in ryegrass plants.

\section{AUTHOR CONTRIBUTIONS}

SP and PC conceived the idea and wrote the manuscript. SP performed all the experiments and PC supervised the research. AG-M and $\mathrm{HJ}$ contributed to evaluation and discussion regarding aspects of the study related to gene expression analyses. KG assisted with management and analysis of the flow cytometry and laser scanning CLSM data. MM contributed to discussion on aspects associated with the influence of $\mathrm{Si}$ on plants subjected to $\mathrm{Al}$ toxicity. All

\section{REFERENCES}

Adrees, M., Ali, S., Rizwan, M., Zia-ur-Rehman, M., Ibrahim, M., Abbas, F., et al. (2015). Mechanisms of silicon-mediated alleviation of heavy metal toxicity in plants: a review. Ecotoxicol. Environ. Saf. 119, 186-197. doi: 10.1016/j.ecoenv. 2015.05.011

Alscher, R. G., Erturk, N., and Heath, L. S. (2002). Role of superoxide dismutases (SODs) in controlling oxidative stress in plants. J. Exp. Bot. 53, 1331-1341. doi: $10.1093 /$ jexbot/53.372.1331

Apel, K., and Hirt, H. (2004). Reactive oxygen species: metabolism, oxidative stress, and signal transduction. Annu. Rev. Plant Biol. 55, 373-399. doi: 10.1146/ annurev.arplant.55.031903.141701

Barcelo, J., Guevara, P., and Poschenrieder, C. H. (1993). Silicon amelioration of aluminium toxicity in teosinte (Zea mays L. ssp. mexicana). Plant Soil 154, 249-255. doi: 10.1007/bf00012530

Barcelo, J., and Poschenrieder, C. (2002). Fast root growth responses, root exudates, and internal detoxification as clues to the mechanisms of aluminium toxicity and resistance: a review. Environ. Exp. Bot. 48, 75-92. doi: 10.1016/S00988472(02)00013-8

Baylis, A. D., Gragopoulou, C., Davidson, K. J., and Birchall, J. D. (1994). Effects of silicon on the toxicity of aluminum to soybean. Commun. Soil Sci. Plant. Anal. 25, 537-546. doi: 10.1080/00103629409369061

Bokor, B., Bokorová, S., Ondos, S., Svubová, R., Lukacova, Z., Hyblova, M., et al. (2014). Ionome and expression level of Si transporter genes (Lsi1, Lsi2, and Lsi6) affected by $\mathrm{Zn}$ and $\mathrm{Si}$ interaction in maize. Environ. Sci. Pollut. Res. Int. 22, 6800-6811. doi: 10.1007/s11356-014-3876-6

Bradford, M. M. (1976). A rapid and sensitive method for the quantitation of microgram quantities of protein utilizing the principle of protein-dye binding. Anal. Biochem. 72, 248-254. doi: 10.1016/0003-2697(76)90527-3

Britez, R. M., Watanabe, T., Jansen, S., Reissmann, C. B., and Osaki, M. (2002). The relationship between aluminium and silicon accumulation in leaves of Faramea marginata (Rubiaceae). New Phytol. 156, 437-444. doi: 10.1046/j.1469-8137. 2002.00531.x

Cartes, P., Jara, A. A., Pinilla, L., Rosas, A., and Mora, M. L. (2010). Selenium improves the antioxidant ability against aluminium-induced oxidative stress in ryegrass roots. Ann. Appl. Biol. 156, 297-307. doi: 10.1111/j.1744-7348.2010. 00387.x

Cartes, P., McManus, M., Wulff-Zottele, C., Gutiérrez, A., and Mora, M. L. (2012). Differential superoxide dismutase expression under aluminium stress in ryegrass cultivars at the short term. Plant Soil 350, 353-363. doi: 10.1007/ s11104-011-0919-3

Chiba, Y., Mitani, N., Yamaji, N., and Ma, J. F. (2009). HvLsi1 is a silicon influx transporter in barley. Plant J. 57, 810-818. doi: 10.1111/j.1365-313X.2008. 03728.x

Cocker, K. M., Evans, D. E., and Hodson, M. J. (1998a). The amelioration of aluminium toxicity by silicon in higher plants: solution chemistry or an in authors contributed to the discussion and approved the final manuscript.

\section{FUNDING}

This work was supported by the FONDECYT projects 1120901 and 1161326, and CONICYT Doctoral Scholarship 21120704.

\section{ACKNOWLEDGMENTS}

The authors are grateful to Scientific and Technological Bioresource Nucleus of Universidad de La Frontera (BIORENUFRO) for providing access to specialized equipment for use in qRT-PCR, flow cytometry, and laser scanning confocal microscopy analysis.

plants mechanism? Physiol. Plant. 104, 608-614. doi: 10.1034/j.1399-3054.1998. 1040413.x

Cocker, K. M., Evans, D. E., and Hodson, M. J. (1998b). The amelioration of aluminium toxicity by silicon in wheat (Triticum aestivum L.): malate exudation as evidence for an in planta mechanism. Planta 204, 318-323. doi: 10.1007/ s004250050262

Corrales, I., Poschenrieder, C., and Barceló, J. (1997). Influence of silicon pretreatment on aluminium toxicity in maize roots. Plant Soil 190, 203-209. doi: 10.1023/A:1004209828791

Delhaize, E., and Ryan, P. R. (1995). Aluminium toxicity and tolerance in plants. Plant Physiol. 107, 315-321. doi: 10.1104/pp.107.2.315

Deshmukh, R., Vivancos, J., Guérin, V., Sonah, H., Labbé, C., Belzile, F., et al. (2013). Identification and functional characterization of silicon transporters in soybean using comparative genomics of major intrinsic proteins in Arabidopsis and rice. Plant Mol. Biol. 83, 303-315. doi: 10.1007/s11103-0130087-3

Donahue, J. L., Okpodu, C. M., Cramer, C. L., Grabau, E. A., and Alscher, R. G. (1997). Responses of antioxidants to paraquat in pea leaves. Relationships to resistance. Plant Physiol. 113, 249-257. doi: 10.2307/4277528

Dorneles, A. O. S., Pereira, A. S., Rossato, L. V., Possebom, G., Sasso, V. M., Bernardy, K., et al. (2016). Silicon reduces aluminum content in tissues and ameliorates its toxic effects on potato plant growth. Cienc. Rural 46, 506-512. doi: 10.1590/0103-8478cr20150585

Du, B., Nian, H., Zhang, Z., and Yang, C. (2010). Effects of aluminum on superoxide dismutase and peroxidase activities, and lipid peroxidation in the roots and calluses of soybeans differing in aluminum tolerance. Acta Physiol. Plant. 32, 883-890. doi: 10.1007/s11738-010-0476-Z

$\mathrm{Du}$, Z., and Bramlage, W. J. (1992). Modified thiobarbaturic acid assay for measuring lipid peroxidation in sugar rich plant tissue extracts. J. Agric. Food Chem. 40, 1566-1570. doi: 10.1021/jf00021a018

Epstein, E. (1999). Silicon. Annu. Rev. Plant Phys. 50, 641-664. doi: 10.1146/ annurev.arplant.50.1.641

Fleck, A. T., Nye, T., Repenning, C., Stahl, F., Zahn, M., and Schenk, M. K. (2010). Silicon enhances suberization and lignification in roots of rice (Oryza sativa). J. Exp. Bot. 62, 2001-2011. doi: 10.1093/jxb/erq392

Fleck, A. T., Schulze, S., Hinrichs, M., Specht, A., Waßmann, F., Schreiber, L., et al. (2015). Silicon promotes exodermal Casparian band formation in Siaccumulating and Si-excluding species by forming phenol complexes. PLoS ONE 10:e0138555. doi: 10.1371/journal.pone.0138555

Foreman, J., Demidchik, V., Bothwell, J. H., Mylona, P., Miedema, H., Torres, M. A., et al. (2003). Reactive oxygen species produced by NADPH oxidase regulate plant cell growth. Nature 422, 442-446. doi: 10.1038/nature 01485

Furukawa, J., Yamaji, N., Wang, H., Mitani, N., Murata, Y., Sato, K., et al. (2007). An Aluminum-activated citrate transporter in barley. Plan Cell Physiol. 8, 1081-1091. doi: 10.1093/pcp/pcm091 
Goodwin, S. B., and Sutter, T. R. (2009). Microarray analysis of Arabidopsis genome response to aluminum stress. Biol. Plant. 53, 85-99. doi: 10.1007/ s10535-009-0012-4

Grégoire, C., Rémus-Borel, W., Vivancos, J., Labbé, C., Belzile, F., and Bélanger, R. (2012). Discovery of a multigene family of aquaporin silicon transporters in the primitive plant Equisetum arvense. Plant J. 72, 320-330. doi: 10.1111/j.1365313X.2012.05082.X

Gunes, A., Pilbeam, D. J., Inal, A., Bagci, E. G., and Coban, S. (2007). Influence of silicon on antioxidant mechanisms and lipid peroxidation in chickpea (Cicer arietinum L.) cultivars under drought stress. J. Plant Interact. 2, 105-113. doi: 10.1080/17429140701529399

Gunes, A., Pilbeam, D. J., Inal, A., and Coban, S. (2008). Influence of silicon on sunflower cultivars under drought stress, I: growth, antioxidant mechanisms, and lipid peroxidation. Commun. Soil Sci. Plant Anal. 39, 1885-1903. doi: 10.1080/00103620802134651

Guntzer, F., Keller, C., and Meunier, J. D. (2012). Benefits of plant silicon for crops: a review. Agron. Sustain. Dev. 32, 201-213. doi: 10.1007/s13593-0110039-8

Gupta, N., Gaurav, S. S., and Kumar, A. (2013). Molecular basis of aluminium toxicity in plants: a Review. Am. J. Plant Sci. 4, 21-37. doi: 10.4236/ajps.2013. $412 \mathrm{~A} 3004$

Habibi, G. (2015). Exogenous silicon leads to increased antioxidant capacity in freezing-stressed pistachio leaves. Acta Agric. Slov. 105, 43-52. doi: 10.14720/ aas.2015.105.1.05

Hara, T., Gu, M. H., and Koyama, H. (1999). Ameliorative effect of silicon on aluminum injury in the rice plant. Soil Sci. Plant Nutr. 45, 929-936. doi: 10.1080/00380768.1999.10414342

Hodson, M. J., and Sangster, A. G. (1993). The interaction between silicon and aluminium in Sorghum bicolor (L.) Moench: growth analysis and X-ray microanalysis. Ann. Bot. 72, 389-400. doi: 10.1006/anbo.1993. 1124

Horst, W. J., Wang, Y., and Eticha, D. (2010). The role of the apoplast in Al induced inhibition of root elongation and in $\mathrm{Al}$ resistance of plants: a review. Ann. Bot. 106, 185-197. doi: 10.1093/aob/mcq053

Huang, C. F., Yamaji, N., Mitani, N., Yano, M., Nagamura, Y., and Ma, J. F. (2009). A bacterial-type $\mathrm{ABC}$ transporter is involved in aluminum tolerance in rice. Plant Cell 21, 655-667. doi: 10.1105/tpc.108.064543

Jarvis, S. C. (1987). The uptake and transport of silicon by perennial ryegrass and wheat. Plant Soil 97, 429-437. doi: 10.1007/BF02383233

Khoshgoftarmanesh, A. H., Khodarahmia, S., and Haghighib, M. (2014). Effect of silicon nutrition on lipid peroxidation and antioxidant response of cucumber plants exposed to salinity stress. Arch. Agron. Soil Sci. 60, 639-653. doi: 10.1080/ 03650340.2013.822487

Kidd, P. S., Llugany, M., Poschenrider, C., Gunse, B., and Barcelo, J. (2001). The role of roots exudates in aluminium resistence and silicon- induced amelioration of aluminium toxicity in three varities of maize (Zea mays L.). J. Exp. Bot. 52, 1339-1352. doi: 10.1093/jexbot/52.359.1339

Kim, Y. H., Khan, A. L., Kim, D. H., and Lee, S. Y. (2014). Silicon mitigates heavy metal stress by regulating P-type heavy metal ATPases, Oryza sativa low silicon genes, and endogenous phytohormones. BMC Plant Biol. 14:13. doi: 10.1186/1471-2229-14-13

Kochian, L. V., Pineros, M. A., and Hoekenga, O. A. (2005). The physiology, genetics and molecular biology of plant aluminum resistance and toxicity. Plant Soil 274, 175-195. doi: 10.1007/s11104-004-1158-7

Li, P., Song, A., Li, Z., Fan, F., and Liang, Y. (2012). Silicon ameliorates manganese toxicity by regulating manganese transport and antioxidant reactions in rice (Oryza sativa L.). Plant Soil 354, 404-419. doi: 10.1007/s11104-0111076-4

Li, Y. C., Sumner, M. E., Miller, W. P., and Alva, A. K. (1996). Mechanism of silicon induced alleviation of aluminum phytotoxicity. J. Plant Nutr. 19, 1075-1087. doi: 10.1080/01904169609365181

Liang, Y., Chen, Q., Liu, Q., Zhang, W., and Ding, R. (2003). Exogenous silicon (Si) increases antioxidant enzyme activity and reduces lipid peroxidation in roots of salt-stressed barley (Hordeum vulgare L.). J. Plant Physiol. 160, 1157-1164. doi: 10.1078/0176-1617-01065

Liang, Y., Nikolic, M., Bélanger, R., Gong, H., and Song, A. (2015). Silicon in Agriculture. Dordrecht: Springer. doi: 10.1007/978-94-017-9978-2
Liang, Y., Sun, W., Zhu, Y. G., and Christie, P. (2007). Mechanisms of silicon mediated alleviation of abiotic stresses in higher plants: a review. Environ. Pollut. 147, 422-428. doi: 10.1016/j.envpol.2006.06.008

Lima, M. D. R., Barros, U. O. Jr., Barbosa, M. A. M., Segura, F. R., Silva, F. F., Batista, B. L., et al. (2016). Silicon mitigates oxidative stress and has positive effects in Eucalyptus platyphylla under aluminium toxicity. Plant Soil Environ. 62, 164-170. doi: 10.17221/85/2016-PSE

Ma, J. F. (2004). Role of silicon in enhancing the resistance of plants to biotic and abiotic stresses. Soil Sci. Plant Nutr. 50, 11-18. doi: 10.1080/00380768.2004. 10408447

Ma, J. F., Sasaki, M., and Matsumoto, H. (1997). Al-induced inhibition of root elongation in corn, Zea mays L. is overcome by Si addition. Plant Soil 188, 171-176. doi: 10.1023/A:1004274223516

Ma, J. F., and Takahashi, E. (2002). Soil, Fertilizer, and Plant Silicon Research in Japan. Amsterdam: Elsevier Science BV.

Ma, J. F., Tamai, K., Yamaji, N., Mitani, N., Konishi, S., Katsuhara, M., et al. (2006). A silicon transporter in rice. Nature 440, 688-691. doi: 10.1038/nature04590

Ma, J. F., and Yamaji, N. (2015). A cooperative system of silicon transport in plants. Trends Plant Sci. 20, 435-442. doi: 10.1016/j.tplants.2015. 04.007

Ma, J. F., Yamaji, N., Mitani, N., Tamai, K., Konishi, S., Fujiwara, T., et al. (2007). An efflux transporter of silicon in rice. Nature 448, 209-212. doi: 10.1038/ nature05964

Ma, Q. F., Rengel, Z., and Kuo, J. (2002). Aluminium toxicity in rye (Secale cereale): root growth and dynamics of cytoplasmic Ca2+in intact root tips. Ann. Bot. 89, 241-244. doi: 10.1093/aob/mcf017

Matsumoto, H. (2000). Cell biology of aluminum toxicity and tolerance in higher plants. Int. Rev. Cytol. 200, 1-46. doi: 10.1016/S0074-7696(00)00001-2

Maxwell, D. P., Wang, Y., and McIntosh, L. (1999). The alternative oxidase lowers mitochondrial reactive oxygen production in plant cultures. Proc. Natl. Acad. Sci. U.S.A. 96, 8271-8276. doi: 10.1073/pnas.96.14.8271

Milla, M. A. R., Butler, E. D., Huete, A. R., Wilson, C. F., Anderson, O., and Gustafson, J. P. (2002). Expressed sequence tag-based gene expression analysis under aluminum stress in rye. Plant Physiol. 130, 1706-1716. doi: 10.1104/pp. 009969

Mitani, N., Yamaji, N., Ago, Y., Iwasaki, K., and Ma, J. F. (2011a). Isolation and functional characterization of an influx silicon transporter in two pumpkin cultivars contrasting in silicon accumulation. Plant J. 66, 231-240. doi: 10.1111/ j.1365-313X.2011.04483.X

Mitani, N., Chiba, Y., Yamaji, N., and Ma, J. F. (2009a). Identification and characterization of maize and barley Lsi2-like silicon efflux transporters reveals a distinct silicon uptake system from that in rice. Plant Cell 21, 2133-2142. doi: 10.1105/tpc.109.067884

Mitani, N., Yamaji, N., and Ma, J. F. (2009b). Identification of maize silicon influx transporters. Plant Cell Physiol. 50, 5-12. doi: 10.1093/pcp/pcn110

Mitani, N., Yamaji, N., and Ma, J. F. (2011b). Silicon efflux transporters isolated from two pumpkin cultivars contrasting in Si uptake. Plant Signal. Behav. 6, 991-994. doi: 10.4161/psb.6.7.15462

Mitani, N., Yamaji, N., and Ma, J. F. (2016). High silicon accumulation in the shoot is required for down-regulating the expression of $\mathrm{Si}$ transporter genes in rice. Plant Cell Physiol. 57, 2510-2518. doi: 10.1093/pcp/pcw163

Montpetit, J., Vivancos, J., Mitani, N., Yamaji, N., Rémus-Borel, W., Belzile, F., et al. (2012). Cloning, functional characterization and heterologous expression of TaLsi1, a wheat silicon transporter gene. Plant Mol. Biol. 79, 35-46. doi: 10.1007/s11103-012-9892-3

Mora, M. L., Alfaro, M. A., Jarvis, S. C., Demanet, R., and Cartes, P. (2006). Soil aluminium availability in Andisols of southern Chile and its effect on forage production and animal metabolism. Soil Use Manag. 22, 95-101. doi: 10.1111/j. 1475-2743.2006.00011.x

Nakano, Y., and Asada, K. (1981). Hydrogen peroxide is scavenged by ascorbatespecific peroxidase in spinach chloroplasts. Plant Cell Physiol. 22, 867-880. doi: 10.1093/oxfordjournals.pcp.a076232

Nanayakkara, U. N., Uddin, W., and Datnoff, L. E. (2008). Effects of soil type, source of silicon, and rate of silicon source on development of gray leaf spot of perennial ryegrass turf. Plant Dis. 92, 870-877. doi: 10.1094/PDIS-92-6-0870

Noctor, G., and Foyer, C. H. (1998). A re-evaluation of the ATP: NADPH budget during C3 photosynthesis. A contribution from nitrate assimilation and its 
associated respiratory activity?. J. Exp. Bot. 49, 1895-1908. doi: 10.1093/jxb/49. 329.1895

Okuno, T., and Furusawa, I. (1977). A simple method for the isolation of intact mesophyll protoplasts from cereal plants. Plant Cell Physiol. 18, 1357-1362. doi: 10.1093/oxfordjournals.pcp.a075558

Panda, S. K., and Matsumoto, H. (2010). Changes in antioxidant gene expression and induction of oxidative stress in pea (Pisum sativum L.) under Al stress. Biometals 23, 753-762. doi: 10.1007/s10534-010-9342-0

Pavlovic, J., Samardzic, J., Maksimovic, V., Timotijevic, G., Stevic, N., Laursen, K. H., et al. (2013). Silicon alleviates iron deficiency in cucumber by promoting mobilization of iron in the root apoplast. New Phytol. 198, 1096-1107. doi: $10.1111 / \mathrm{nph} .12213$

Peng, C. L., Ou, Z. Y., Liu, N., and Lin, G. Z. (2005). Response of flag leaves of super high-yielding rice Pei'ai 64S/E32 and liangyoupeijiu to high temperature. Rice Sci. 12, 179-186.

Pinhero, R. G., Rao, M. V., Paliyath, G., Murr, D. P., and Fletcher, R. A. (1997). Changes in activities of antioxidant enzymes and their relationship to genetic and paclobutrazol-induced chilling tolerance of maize seedlings. Plant Physiol. 114, 695-704. doi: 10.1104/pp.114.2.695

Pontigo, S., Ribera, A., Gianfreda, L., Mora, M. L., Nikolic, M., and Cartes, P. (2015). Silicon in vascular plants: uptake, transport and its influence on mineral stress under acidic conditions. Planta 242, 23-37. doi: 10.1007/s00425-0152333-1

Poschenrieder, C., Gunse, B., Corrales, I., and Barcelo, J. (2008). A glance into aluminum toxicity and resistance in plants. Sci. Total Environ. 400, 356-368. doi: 10.1016/j.scitotenv.2008.06.003

Prabagar, S., Hodson, M. J., and Evans, D. E. (2011). Silicon amelioration of aluminium toxicity and cell death in suspension cultures of Norway spruce (Picea abies L. Karst.). Environ. Exp. Bot. 70, 266-276. doi: 10.1016/j.envexpbot. 2010.10.001

Ribera, A., Inostroza-Blancheteau, C., Cartes, P., Rengel, Z., and Mora, M. L. (2013). Early induction of Fe-SOD gene expression is involved in tolerance to $\mathrm{Mn}$ toxicity in perennial ryegrass. Plant Physiol. Biochem. 73, 77-82. doi: 10.1016/j.plaphy.2013.08.012

Ryan, P. R., and Delhaize, E. (2010). The convergent evolution of aluminium resistance in plants exploits a convenient currency. Funct. Plant Biol. 37, 275-284. doi: 10.1071/FP09261

Ryan, P. R., Tyerman, S. D., Sasaki, T., Furuichi, T., Yamamoto, Y., Zhang, W. H., et al. (2011). The identification of aluminium-resistance genes provides opportunities for enhancing crop production on acid soils. J. Exp. Bot. 62, 9-20. doi: $10.1093 /$ jxb/erq272

Sasaki, T., Yamamoto, Y., Ezaki, B., Kasuara, M., Ju Ahn, S., Ryan, P., et al. (2004). A wheat gene encoding an aluminum-activated malate transporter. Plant J. 37, 645-653. doi: 10.1111/j.1365-313X.2003.01991.x

Sadzawka, A., Carrasco, M. A., Demanet, R., Flores, H., Grez, R., Mora, M. L., et al. (2007). Métodos de Análisis de Tejidos Vegetales. Segunda Edición. Serie Actas INIA $\mathrm{N}^{\circ}$ 40. Santiago: Instituto de Investigaciones Agropecuarias.

Shaff, J. E., Schultz, B. A., Craft, E. J., Clark, R. T., and Kochian, L. V. (2010). GEOCHEM-EZ: a chemical speciation program with greater power and flexibility. Plant Soil 330, 207-214. doi: 10.1007/s11104-0090193-9

Shahnaz, G., Shekoofeh, E., Kourosh, D., and Moohamadbagher, B. (2011). Interactive effects of silicon and aluminum on the malondialdehyde (MDA), proline, protein and phenolic compounds in Borago officinalis L. J. Med. Plants Res. 5, 5818-5827.

Shen, X., Xiao, X., Dong, Z., and Chen, Y. (2014). Silicon effects on antioxidative enzymes and lipid peroxidation in leaves and roots of peanut under aluminum stress. Acta Physiol. Plant. 36, 3063-3069. doi: 10.1007/s11738-0141676-8

Shetty, R., Frette, X., Jensen, B., Shetty, N. P., Jensen, J. D., Jørgen, H., et al. (2011). Silicon-induced changes in antifungal phenolic acids, flavonoids, and key phenylpropanoid pathway genes during the interaction between miniature roses and the biotrophic pathogen Podosphaera pannosa. Plant Physiol. 157, 2194-2205. doi: 10.1104/pp.111.185215

Shi, Q., Bao, Z., Zhu, Z., He, Y., Qian, Q., and Yu, J. (2005). Silicon mediated alleviation of $\mathrm{Mn}$ toxicity in Cucumis sativus in relation to activities of superoxide dismutase and ascorbate peroxidase. Phytochemistry 66, 1551-1559. doi: $10.1016 /$ j.phytochem.2005.05.006
Singh, S., Tripathi, D. K., Singh, S., Sharma, S., Dubey, N. K., Chauhan, D. K., et al. (2017). Toxicity of aluminium on various levels of plant cells and organism: a review. Environ. Exp. Bot. 137, 177-193. doi: 10.1016/j.envexpbot.2017. 01.005

Singh, V. P., Tripathi, D. K., Kumar, D., and Chauhan, D. K. (2011). Influence of exogenous silicon addition on aluminium tolerance in rice seedlings. Biol. Trace Elem. Res. 144, 1260-1274. doi: 10.1007/s12011-011-9118-6

Sivaguru, M., Ezaki, B., He, Z. H., Tong, H., Osawa, H., Baluška, F., et al. (2003). Aluminum-induced gene expression and protein localization of a cell wall-associated receptor kinase in Arabidopsis. Plant Physiol. 132, 2256-2266. doi: 10.1104/pp.103.022129

Slinkard, K., and Singleton, V. A. (1977). Total phenol analysis: automation and comparison with manual methods. Am. J. Enol. Vitic. 28, 29-55. doi: 10.3390/ molecules 15128618

Song, A., Xue, G., Cui, P., Fan, F., Liu, H., Yin, C., et al. (2016). The role of silicon in enhancing resistance to bacterial blight of hydroponic-and soil-cultured rice. Sci. Rep. 6:24640. doi: 10.1038/srep24640

Takahashi, M. A., and Asada, K. (1983). Superoxide anion permeability of phospholipid membranes and chloroplast thylakoids. Arch. Biochem. Biophys. 226, 558-566. doi: 10.1016/0003-9861(83)90325-9

Taylor, G. J., and Foy, C. D. (1985). Mechanisms of aluminum tolerance in Triticum aestivum L. (wheat). II. Differential $\mathrm{pH}$ induced by spring cultivars in nutrient solutions. Am. J. Bot. 72, 695-701. doi: 10.2307/2443682

Tripathi, D. K., Bashri, G., Singh, S., Singh, S., Ahmad, P., Prassad, S. M., et al. (2016). "Efficacy of silicon against aluminum toxicity in plants: an overview," in Silicon in Plants: Advances and Future Prospects, eds D. K. Tripathi, V. P. Singh, P. Ahmad, D. K. Chauhan, and S. M. Prasad (Boca Raton, FL: CRC Press), 355-366. doi: 10.1201/978131536 9310-20

Tripathi, D. K., Singh, V. P., Prasad, S. M., Chauhan, D. K., Dubey, N. K., and Rai, A. K. (2015). Silicon-mediated alleviation of Cr (VI) toxicity in wheat seedlings as evidenced by chlorophyll florescence, laser induced breakdown spectroscopy and anatomical changes. Ecotoxicol. Environ. Saf. 113, 133-144. doi: 10.1016/j.ecoenv.2014.09.029

Vaculík, M., Landberg, T., Greger, M., Luxová, M., Stoláriková, M., and Lux, A. (2012). Silicon modifies root anatomy, and uptake and subcellular distribution of cadmium in young maize plants. Ann. Bot. 110, 433-443. doi: 10.1093/aob/ mcs039

von Uexküll, H. R., and Mutert, E. (1995). "Global extent, development and economic impact of acid soils," in Plant-Soil Interactions at Low pH: Principles and Management, eds R. A. Date, N. J. Grundon, G. E. Rayment, and M. E. Probert (Dordrecht: Springer), 5-19. doi: 10.1007/978-94-0110221-6_1

Vulavala, V. K., Elbaum, R., Yermiyahu, U., Fogelman, E., Kumar, A., and Ginzberg, I. (2016). Silicon fertilization of potato: expression of putative transporters and tuber skin quality. Planta 243, 217-229. doi: 10.1007/s00425015-2401-6

Wang, Y., Stass, A., and Horst, W. J. (2004). Apoplastic binding of aluminum is involved in silicon-induced amelioration of aluminum toxicity in maize. Plant Physiol. 136, 3762-3770. doi: 10.1104/pp.104.045005

Yamaji, N., Chiba, Y., Mitani, N., and Ma, J. F. (2012). Functional characterization of a silicon transporter gene implicated in silicon distribution in barley. Plant Physiol. 160, 1491-1497. doi: 10.1104/pp.112.204578

Yamaji, N., and Ma, J. F. (2009). A transporter at the node responsible for intervascular transfer of silicon in rice. Plant Cell 21, 2878-2883. doi: 10.1105/ tpc.109.069831

Yamaji, N., Mitani, N., and Ma, J. F. (2008). A transporter regulating silicon distribution in rice shoots. Plant Cell 20, 1381-1389. doi: 10.1105/tpc.108. 059311

Yamamoto, Y., Kobayashi, Y., Devi, S. R., Rikiishi, S., and Matsumoto, H. (2002). Aluminum toxicity is associated with mitochondrial dysfunction and the production of reactive oxygen species in plant cells. Plant Physiol. 128, 63-72. doi: 10.1104/pp.010417

Yamamoto, Y., Kobayashi, Y., Devi, S. R., Rikiishi, S., and Matsumoto, H. (2003). Oxidative stress triggered by aluminum in plant roots. Plant Soil 255, 239-243. doi: 10.1023/A:1026127803156

Yamamoto, Y., Kobayashi, Y., and Matsumoto, H. (2001). Lipid peroxidation is an early symptom triggered by aluminum, but not the primary cause of elongation 
inhibition in pea roots. Plant Physiol. 125, 199-208. doi: 10.1104/pp.125. 1.199

Zhang, G., Cui, Y., Ding, X., and Dai, Q. (2013). Stimulation of phenolic metabolism by silicon contributes to rice resistance to sheath blight. J. Plant Nutr. Soil Sci. 176, 118-124. doi: 10.1002/jpln.201200008

Zhu, Z., Wei, W., Li, J., Qian, Q., and Yu, J. (2004). Silicon alleviates salt stress and increases antioxidant enzymes activity in leaves of salt-stressed cucumber (Cucumis sativus L.). Plant Sci. 167, 527-533. doi: 10.1016/j.plantsci.2004. 04.020

Zia-ur-Rehman, M., Khalid, H., Akmal, F., Waqar, M., Rizwan, M., Qayyum, F., et al. (2016). "Silicon and antioxidant defense system against abiotic stresses in plants: an overview," in Silicon in Plants: Advances and Future Prospects, eds D. K. Tripathi, V. P. Singh, P. Ahmad, D. K. Chauhan, and S. M. Prasad (Boca Raton, FL: CRC Press), 321-342. doi: 10.1201/978131536 9310-18
Zsoldos, F., Vashegyi, A., Pecsvaradi, A., and Bona, L. (2003). Influence of silicon on aluminium toxicity in common and durum wheats. Agronomie 23, 349-354. doi: 10.1051/agro:2003008

Conflict of Interest Statement: The authors declare that the research was conducted in the absence of any commercial or financial relationships that could be construed as a potential conflict of interest.

Copyright (๔ 2017 Pontigo, Godoy, Jiménez, Gutiérrez-Moraga, Mora and Cartes. This is an open-access article distributed under the terms of the Creative Commons Attribution License (CC BY). The use, distribution or reproduction in other forums is permitted, provided the original author(s) or licensor are credited and that the original publication in this journal is cited, in accordance with accepted academic practice. No use, distribution or reproduction is permitted which does not comply with these terms. 